\title{
KERANGKA PERATURAN PERUNDANG-UNDANGAN PROGRAM PEMBANGUNAN PLTN
}

\author{
Ferhat Aziz dan Yaziz Hasan \\ Biro Kerja Sama, Hukum, dan Hubungan Masyarakat - BATAN \\ Jalan Kuningan Barat, Mampang Prapatan, Jakarta Selatan, 12070
}

\begin{abstract}
ABSTRAK
KERANGKA PERATURAN PERUNDANG-UNDANGAN PROGRAM PEMBANgUnAN PLTN. Pengembangan program PLTN harus didasarkan pada komitmen untuk menggunakan tenaga nuklir hanya untuk tujuan damai, dengan cara yang aman dan selamat, yang mengharuskan adanya infrastruktur nasional yang berkelanjutan yang melibatkan berbagai aspek, seperti kerangka peraturan perundangundangan. Kerangka tersebut berkaitan dengan pembentukan badan regulator independen dan penyusunan peraturan tentang nuklir, yaitu proteksi radiasi, bahan radioaktif dan sumber radiasi, keamanan instalasi nuklir, kesiapsiagaan kedaruratan dan tindakan tanggap darurat, penambangan dan pengolahan, transportasi, limbah radioaktif dan bahan bakar bekas, pertanggungjawaban kerugian nuklir dan kompensasi, proteksi, kontrol ekspor dan impor, dan proteksi fisik, sesuai konvensi dan standar internasional. Untuk itu, pemerintah telah menerbitkan berbagai peraturan perundang-undangan di bidang nuklir guna menjamin keamanan dan keselamatan pekerja, masyarakat maupun lingkungan hidup dari bahaya radiasi yang mungkin timbul.
\end{abstract}

Kata kunci: peraturan perundang-undangan ketenaganukliran, konvensi internasional, keselamatan, keamanan, seifgard dan pertanggungjawaban.

\section{ABSTRACT}

LEGISLATIVE AND REGULATORY FRAMEWORK OF NPP DEVELOPMENT PROGRAM. Development of nuclear power program should be based on a commitment to use nuclear energy for peaceful purposes only, in a safe and secure manner, which requires the existence of a sustainable national infrastructure that involves many aspects, such as legislative and regulatory framework. The framework is related to the establishment of an independent regulatory body and the preparation of regulations on nuclear activities, such as radiation protection, radioactive materials and radiation sources, nuclear plant security, emergency preparedness and emergency response actions, mining and processing, transportation, radioactive waste and spent fuel, nuclear damage liability and compensation, protection, export and import controls, and physical protection, according to the international conventions and standards. Therefore, the government has issued various nuclear regulations in order to ensure the security and safety of workers, people and the environment from radiation hazards that may arise.

Keywords: nuclear energy legislation, international conventions, safety, security, safeguard and liability.

\section{PENDAHULUAN}

Dalam rangka pembangunan pembangkit listrik tenaga nuklir (PLTN) terdapat beberapa perangkat infrastruktur yang perlu dipersiapkan. Program nuklir adalah sebuah upaya yang membutuhkan perencanaan, investasi dan persiapan sumber daya manusia.

Keputusan untuk mengembangkan program PLTN harus didasarkan pada komitmen untuk menggunakan tenaga nuklir hanya untuk tujuan damai, dengan cara yang aman dan selamat. Komitmen ini mengharuskan adanya suatu infrastruktur nasional yang berkelanjutan yang melibatkan aspek pemerintahan, peraturan perundang-undangan, manajerial, teknologi, sumber daya manusia dan industri sepanjang siklus program nuklir. Unjuk kepatuhan terhadap instrumen hukum internasional, standar keselamatan nuklir yang diterima secara internasional, panduan keamanan nuklir dan persyaratan seifgard (safeguard) sangat penting dalam membangun program nuklir yang bertanggung jawab.

Pengembangan infrastruktur yang tepat untuk mendukung keberhasilan program nuklir dan penggunaannya yang aman dan efisien merupakan 
isu yang harus menjadi perhatian, terutama bagi Indonesia yang sedang mempersiapkan PLTN yang pertama. Infrastruktur yang dibutuhkan untuk mendukung pelaksanaan PLTN mencakup berbagai aspek, dari fasilitas fisik dan peralatan yang terkait dengan pengiriman listrik, pengangkutan bahan dan perlengkapan ke tapak, tapak itu sendiri, fasilitas untuk penanganan limbah radioaktif, kerangka hukum dan peraturan, sumber daya manusia dan keuangan. Singkatnya, infrastruktur yang meliputi semua kegiatan dan pengaturan yang diperlukan untuk mendukung pengoperasian program nuklir.

Pengembangan program nuklir memerlukan perhatian terhadap isu-isu kompleks dan saling berhubungan selama waktu lama. Introduksi program nuklir melibatkan komitmen setidaknya 100 tahun untuk menjamin infrastruktur nasional yang berkelanjutan selama pengoperasian, dekomisioning dan pengelolaan/penyimpanan limbah lestari. Pengalaman menunjukkan bahwa kerangka waktu dari pengambilan keputusan hingga pengoperasian PLTN pertama berkisar antara 10-15 tahun. Kerangka waktu tersebut dapat lebih lama tergantung pada sumber daya yang dicurahkan selama proses pembangunan.

Pilihan meluncurkan program nuklir merupakan komitmen penting yang memerlukan perhatian khusus pada aspek keselamatan dan pengendalian bahan nuklir. Komitmen ini tidak hanya mencakup tanggung jawab terhadap warga negara yang mengembangkan program tersebut, tetapi juga tanggung jawab terhadap masyarakat internasional.

Tujuan pokok keselamatan nuklir adalah untuk melindungi masyarakat dan lingkungan dari efek bahaya radiasi pengion. Untuk itu, perlu dikembangkan suatu kerangka keselamatan komprehensif yang mencakup semua tahapan kegiatan pembangunan. Salah satu pilihan untuk pengembangan kerangka kerja ini adalah menggunakan informasi yang ada dalam 'Prinsip Keselamatan Fundamental' IAEA, yang berisi sepuluh prinsip keselamatan yang menjadi konsensus internasional tentang tingkat keamanan yang dibutuhkan untuk pemanfaatan nuklir secara berkelanjutan. Prinsip pertama menetapkan bahwa tanggung jawab utama keselamatan harus berada pada operator.

Selain keselamatan nuklir, dan tidak kurang pentingnya, adalah isu-isu yang terkait dengan pengendalian (pengawasan) bahan nuklir, baik untuk menjamin keamanan bahan, atau untuk memastikan bahwa semua kegiatan tidak mengandung risiko proliferasi senjata nuklir dan bahwa semua bahan cukup dipertanggungjawabkan dan diawasi. Ini memerlukan pengembangan budaya, sistem dan praktek yang memastikan bahwa semua pihak mengetahui tanggung jawabnya dan tindakan apa yang harus dilakukannya.
Poin-poin penting yang harus dipenuhi dalam rangka komitmen tersebut antara lain:

1. Perlunya memastikan keselamatan, keamanan dan non-proliferasi bahan nuklir;

2. Perlunya menjadi pihak pada perjanjian dan konvensi internasional yang relevan;

3. Perlunya mengembangkan suatu kerangka peraturan perundang-undangan yang komprehensif yang mencakup semua aspek hukum nuklir, yaitu keselamatan, keamanan, seifgard (safeguard), dan pertanggungjawaban kerugian nuklir dan aspek komersialnya;

4. Perlunya badan pengawas yang independen, kompeten dan efektif;

5. Perlunya mengembangkan dan mempertahankan kemampuan sumber daya nasional baik dalam sektor pemerintah maupun industri agar dapat mengelola, mengoperasikan, memelihara dan mengatur fasilitas nuklir;

6. Adanya suatu undang-undang dan penerapan instrumen hukum internasional yang relevan;

7. Adanya suatu sistem negara untuk akuntansi dan pengendalian bahan nuklir (SSAC) yang efektif;

8. Penetapan modalitas keuangan dan operasional untuk kepemilikan dan pengoperasian fasilitas nuklir, termasuk kepemilikan pemerintah dan/atau swasta dan kepemilikan asing;

9. Penetapan kebijakan untuk daur bahan bakar nuklir, termasuk pengaturan sumber pasokan, transportasi dan penyimpanan dan pengelolaan bahan bakar bekas dan limbah radioaktif;

10. Penetapan hukum, organisasi dan pengaturan keuangan untuk dekomisioning dan kewajiban pengelolaan limbah radioaktif;

11. Adanya keterlibatan para pemangku kepentingan mengenai program nuklir;

12. Penetapan kebijakan untuk partisipasi nasional dan industri dalam program nuklir dan memulai program-program untuk pengembangan sumber daya manusia dan fisik yang diperlukan untuk melaksanakan kebijakan tersebut;

13. Pengembangan program seifgard nasional untuk bahan nuklir;

14. Pengembangan program keamanan bahan nuklir dan fasilitas;

15. Pengembangan program proteksi radiasi dan rencana kedaruratan; dan

16. Penerapan standar internasional untuk perlindungan lingkungan.

Untuk mencapai titik kesiapan mengoperasikan PLTN, pemerintah harus membangun infrastruktur dasar yang berhubungan dengan sistem perizinan, pengaturan dan 
pengoperasian yang aman dan konsisten dengan komitmen internasional. Melakukan pemantauan pengembangan dan memastikan kompetensi organisasi dan lembaga yang bertanggungjawab atas pembangunan, pengoperasian dan peraturan semua kegiatan terkait.

Makalah ini akan menyajikan uraian tentang kerangka hukum dan peraturan dalam pengembangan infrastruktur nuklir nasional, yang diperlukan untuk memulai pembangunan PLTN dengan semua kompetensi dan kemampuan yang diperlukan untuk dapat mengatur dan mengoperasikan PLTN sepanjang hidupnya dengan aman, selamat dan ekonomis, dan bagaimana mengatur dan mengelola limbah radioaktifnya.

Uraian yang disajikan meliputi perjanjian internasional ketenaganukliran, aspek-aspek hukum nuklir, yaitu keselamatan, keamanan, seifgard (safeguard), dan pertanggungjawaban kerugian nuklir, serta proses transformasi perjanjian internasional tersebut kedalam peraturan perundang-undangan nuklir nasional.

\section{HUKUM NUKLIR}

\section{Hirarki Hukum Nuklir Nasional}

Penting untuk disadari bahwa norma-norma hukum pengaturan energi nuklir merupakan bagian dari sistem umum hukum nasional, yang harus diletakkan di dalam hirarki hukum biasa. Hirarki ini terdiri dari beberapa tingkatan. Yang pertama, biasanya disebut sebagai tingkat konstitusional, menetapkan struktur kelembagaan dan hukum dasar yang mengatur semua hubungan di dalam negara. Di bawah tingkat konstitusional adalah tingkat statuta, yaitu undang-undang khusus yang ditetapkan oleh parlemen dalam rangka membangun badan-badan yang diperlukan dan untuk mengambil langkahlangkah yang berkaitan dengan berbagai kegiatan yang mempengaruhi kepentingan nasional. Tingkat ketiga terdiri dari peraturan yang rinci dan seringkali merupakan aturan sangat teknis untuk mengontrol atau mengatur kegiatan yang ditentukan oleh instrumen hukum. Karena karakternya yang khusus, aturan tersebut biasanya dikembangkan oleh badan ahli yang diberdayakan untuk mengawasi bidangbidang tertentu yang menyangkut kepentingan nasional. Tingkat keempat terdiri dari instrumen panduan tidak mengikat, yang berisi rekomendasi yang dirancang untuk membantu orang dan organisasi dalam memenuhi persyaratan hukum.

Pemanfaatan teknologi nuklir dapat melibatkan penerapan berbagai hukum terutama yang berkaitan dengan bidang lain, seperti perlindungan lingkungan, keselamatan industri, perencanaan pemanfaatan lahan, prosedur administrasi, pertambangan, transportasi, etika dan bahkan peraturan tarif listrik.

\section{Internasionalisasi Hukum Nuklir}

Salah satu ciri hukum nuklir adalah tingkat 'internasionalisasi'-nya yang tinggi, yang berarti bahwa kewajiban, rekomendasi, standar dan instrumen internasional lainnya harus diperhitungkan dalam proses perumusan hukum nasional atau mempengaruhi hukum nuklir nasional dalam beberapa cara. Para penyusun peraturan perundang-undangan terikat pada berbagai bentuk perjanjian nuklir internasional dan terikat oleh berbagai kewajiban internasional di bidang nuklir. Pendekatan tersebut membutuhkan aproksimasi atau harmonisasi rezim legal nasional, demi keuntungan para pemangku kepentingan terhadap penggunaan energi nuklir dan radiasi pengion, khususnya mempertimbangkan potensi yang berakibat lintas batas antar negara. Prinsip kerja sama internasional diidentifikasi sebagai salah satu konsep dasar hukum nuklir.

Regulasi nuklir juga sangat diperlukan dalam membangun kepercayaan publik. Untuk mencapai hal itu perlu kerangka hukum yang komprehensif dan efektif yang tujuannya adalah perlindungan kesehatan, keselamatan dan keamanan publik serta integritas lingkungan hidup. Kepercayaan masyarakat juga membutuhkan kepercayaan pada institusi yang terlibat, baik regulator maupun operator. Hal ini, pada gilirannya, mengharuskan antara lain transparansi dan komunikasi proaktif.

Kerangka hukum yang efektif tergantung pada persyaratan yang ketat, serta langkah-langkah penegakan hukum untuk memastikan kepatuhan terhadap persyaratan. Pada saat yang sama, kerangka kerja ini harus fleksibel dalam mengikuti perubahan teknologi dan perkembangan masyarakat. Akhirnya, karena konsekuensi penggunaan energi nuklir yang mungkin tidak terbatas dalam batas wilayah nasional, kerangka kerja ini harus bersifat internasional.

Perkembangan ilmu pengetahuan dan teknologi nuklir perlu diiringi dengan persyaratan legislatif yang berpacu dengan pemanfaatan teknologi baru. Dengan demikian, peraturan perundang-undangan perlu diperluas jangkauannya dengan tujuan untuk melindungi masyarakat dan lingkungan dari risiko yang terkait dengan perkembangan baru ini.

Akibatnya, kebutuhan legislatif tersebut mencakup berbagai kegiatan yang sangat luas, yang meliputi:

1. penambangan dan pengolahan uranium;

2. penggunaan bahan nuklir dan radiasi dalam penelitian, kesehatan dan industri;

3. pengemasan dan transportasi bahan radioaktif termasuk bahan bakar nuklir;

4. keselamatan nuklir pada semua tahapan kehidupan instalasi nuklir, dari pembangkit listrik hingga unit terapi radiasi, dan dari desain hingga dekomisioning; 
5. proteksi fisik (keamanan) bahan nuklir dan instalasi nuklir;

6. perdagangan internasional bahan nuklir, peralatan dan teknologi;

7. pengelolaan bahan bakar bekas dan limbah radioaktif;

8. non-proliferasi dan kewajiban seifgard;

9. kesiapsiagaan kedaruratan radiologi dan tindakan tanggap darurat;

10. Pertanggungjawaban dan kompensasi atas kerugian yang diderita sebagai akibat kecelakaan.

Sebagian besar persyaratan legislatif berasal dari, atau didasarkan pada, prinsip-prinsip dan standar yang diterima secara internasional.

\section{PERJANJIAN INTERNASIONAL KETENAGANUKLIRAN}

\section{Keselamatan Nuklir}

\section{Isu Keselamatan Nuklir Pasca Chernobyl}

Dalam pengertian sempit keselamatan nuklir merujuk pada penanganan yang berkaitan dengan daur bahan bakar nuklir, sedangkan keselamatan radiasi berkaitan dengan risiko-risiko yang mungkin timbul dari penggunaan radiasi pengion, termasuk penggunaan radioisotop dan radiasi dalam kedokteran, industri dan berbagai bidang lainnya. Selanjutnya, keselamatan manajemen limbah berkaitan dengan risiko-risiko yang mungkin timbul dari limbah radioaktif termasuk penyimpanan dan pembuangannya. Namun dalam konteks ini 'keselamatan nuklir' digunakan sebagai payung yang mencakup semua aktivitas tersebut.

Pada level internasional, IAEA dalam program NUSS-nya yang diluncurkan pada 1974, memberikan definisi keselamatan nuklir sebagai berikut:

"Tercapainya syarat-syarat pengoperasian yang benar, pencegahan kecelakaan atau mitigasi akibatakibat kecelakaan, yang mengharuskan perlindungan personel tapak, masyarakat umum dan lingkungan dari bahaya radiasi yang tidak diinginkan".

Peristiwa Chernobyl yang terjadi 25-26 April 1986 telah memicu suatu tindakan segera yang berkelanjutan dan komprehensif dari masyarakat Internasional yang menghasilkan sejumlah instrumen internasional baru, yang disajikan dalam Tabel 1, yang ditujukan untuk mengatasi kelemahan rezim hukum internasional pra-1986 yang terbukti tidak berjalan efektif.
Tabel 1 Konvensi-konvensi Pasca-Chernobyl

\begin{tabular}{|c|c|}
\hline Nama Konvensi & Tanggal Adopsi \\
\hline $\begin{array}{l}\text { Convention on Early Notification } \\
\text { of a Nuclear Accident }\end{array}$ & $\begin{array}{l}26 \text { September } \\
1986\end{array}$ \\
\hline $\begin{array}{l}\text { Convention on Assistance in the } \\
\text { Case of Nuclear Accident or } \\
\text { Radiological Emergency }\end{array}$ & $\begin{array}{l}26 \text { September } \\
1986\end{array}$ \\
\hline $\begin{array}{l}\text { Joint Protocol Relating in the } \\
\text { Application of the Vienna } \\
\text { Convention and the Paris } \\
\text { Convention }\end{array}$ & $\begin{array}{l}21 \text { September } \\
1988\end{array}$ \\
\hline $\begin{array}{l}\text { Convention on Nuclear Safety } \\
\text { Joint Convention on the Safety of } \\
\text { Spent Fuel Management and the } \\
\text { Safety of Radioactive Waste } \\
\text { Management }\end{array}$ & $\begin{array}{l}17 \text { Juni } 1994 \\
5 \quad \text { September } \\
1997\end{array}$ \\
\hline $\begin{array}{l}\text { Protocol to Amend the } 1963 \text { Vienna } \\
\text { Convention on Civil Liability for } \\
\text { Nuclear Damage }\end{array}$ & $\begin{array}{l}12 \text { September } \\
1997\end{array}$ \\
\hline $\begin{array}{l}\text { Convention on Supplementary } \\
\text { Compensation for Nuclear Damage }\end{array}$ & $\begin{array}{ll}12 & \text { September } \\
1997 & \end{array}$ \\
\hline $\begin{array}{l}\text { Protocol to Amend the Convention } \\
\text { on Third Party Liability in the } \\
\text { Field of Nuclear Energy of } 29 \text { July } \\
1960 \text {, as Amendedby the Additional } \\
\text { Protocol of } 28 \text { January } 1964 \text { and } \\
\text { by the Protocol of } 16 \text { November } \\
1982\end{array}$ & $\begin{array}{l}12 \\
2004\end{array}$ \\
\hline $\begin{array}{l}\text { Protocol to Amend the Convention } \\
\text { of } 31 \text { January } 1963 \text { Supplementary } \\
\text { to the Paris Convention of } 29 \text { July } \\
1960 \text { on Third Party Liability in the } \\
\text { Field of Nuclear Energy, as } \\
\text { Amended by the Additional } \\
\text { Protocol of } 28 \text { January } 1964 \text { and } \\
\text { by the Protocol of } 16 \text { November } \\
1982\end{array}$ & $\begin{array}{l}12 \\
2004\end{array}$ \\
\hline $\begin{array}{l}\text { Amendment to the Convention on } \\
\text { the Physical Protection of Nuclear } \\
\text { Material }\end{array}$ & 8 Juli 2005 \\
\hline
\end{tabular}

Semua traktat pada Tabel 1 adalah instrumen internasional multilateral dan bersifat mengikat, yang hampir semuanya telah berlaku efektif, dengan kekecualian Convention on Supplementary Compensation for Nuclear Damage 1997; Protocols to Amend the Paris and the Brussel Conventions 2004 dan Amendment to the Convention on the Physical Protection of Nuclear Material 2005. Kendati Amendment to the Convention on the Physical Protection of Nuclear Material 2005 mungkin tidak harus dikualifikasikan sebagai reaksi langsung terhadap peristiwa Chernobyl karena dia dirancang untuk mengantisipasi peningkatan ancaman terorisme, instrumen ini tetap dihitung dalam pengertian ini. Terdapat bidang antarmuka antara keselamatan dan keamanan yang memerlukan perhatian. Langkah-langkah proteksi fisik, sebagai efek samping, memperkuat keselamatan nuklir dan sebaliknya. Sebagai akibatnya, Convention on the Physical Protection of 
Nuclear Material merupakan bagian dari apa yang disebut Keluarga Konvensi Keselamatan Nuklir, anggota lainnya adalah the Convention on Early Notification of a Nuclear Accident; the Convention on Assistance in the Case of Nuclear Accident or Radiological Emergency, the Convention on Nuclear Safety, dan the Joint Convention on the Safety of Spent Fuel Management and the Safety of Radioactive Waste Management.

Di samping traktat internasional yang mengikat tersebut di atas, berbagai instrumen internasional tidak mengikat juga telah dikembangkan sejak 1986, sebagai kelanjutan usaha yang telah ada sejak pendirian IAEA dan organisasi kompeten lainnya. Khususnya, berupa rekomendasi-rekomendasi teknis dalam bidang keselamatan nuklir, proteksi radiasi dan transportasi dengan memperbarui rekomendasi yang telah ada atau yang baru dikembangkan Ini dikembangkan oleh kelompok ahli INSAG dan dipublikasikan oleh IAEA.

Salah satu yang terpenting adalah "Code of Conduct on the Safety of Research Reactors" yang ditetapkan oleh Dewan Gubernur IAEA pada 8 Maret 2004. Sebagaimana diketahui, lingkup aplikasi Konvensi Keselamatan Nuklir 1994 hanya mencakup PLTN sipil yang berada di darat dan sebagai akibatnya sebagian besar reaktor riset di seluruh dunia tidak dicakup di dalamnya. Pengecualian ini bersifat politis, salah satunya karena reaktor-reaktor riset sering berfungsi ganda (dual-purpose). Instrumen Code of Conduct tidak mengikat ini menawarkan kompromi agar negaranegara sudi menjadikan reaktor-reaktor riset mereka sebagai subyek rezim internasional yang mengikat. Kode tersebut merupakan komplemen penting terhadap Convention on Nuclear Safety.

Code of Conduct lainnya adalah "Code of Conduct on the Safety and Security of Radioactive Sources" yang disetujui oleh Dewan Gubernur IAEA pada 8 September 2003. Sumber-sumber radioaktif bukan merupakan bagian dari daur bahan bakar nuklir. Di lain pihak sumber-sumber radioaktif secara berulang terkait dalam kecelakaan radiasi, yang paling terkenal adalah peristiwa Goiania (Brazil) 1987. Karena, terkait dengan sumber radioaktif, masih ada ketimpangan dalam rezim legal pada level nasional dan internasional, situasi ini juga memerlukan tindakan internasional. Code of Conduct ini merupakan respons terhadap hal ini.

\section{Konvensi Keselamatan Nuklir dan Konvensi Gabungan}

Peristiwa Chernobyl telah menciptakan kesadaran pada level politis bahwa keselamatan nuklir tidak dapat sepenuhnya diletakkan pada filosofi keselamatan masing-masing individual negara. Seluruh daur bahan bakar nuklir dan khususnya seluruh usia hidup fasilitas nuklir harus dicakup dalam langkah-langkah keselamatan sebagaimana mestinya yang diterima secara internasional. Ini diwujudkan dengan penetapan suatu 'konvensi keselamatan nuklir'.

Setelah melalui perundingan yang sulit secara politis, Convention on Nuclear Safety dan the Joint Convention on the Safety of Spent Fuel Management and the Safety of Radioactive Waste Management akhirnya diadopsi. Kedua konvensi memberikan pijakan baru, dimana untuk pertama kalinya prinsip-prinsip dasar tertentu keselamatan nuklir dinyatakan wajib di dalam kerangka teknis pengembangan aspek hukum.

Konvensi Keselamatan Nuklir (Convention on Nuclear Safety) bertujuan untuk melibatkan secara legal partisipasi Negara-negara Pihak yang mengoperasikan PLTN untuk menjaga keselamatan tingkat tinggi dengan menetapkan standar-standar (benchmarks) internasional yang harus dianut. Kewajiban-kewajiban Negara Pihak didasarkan pada sejumlah prinsip yang terkandung dalam dokumen Pokok-pokok Keselamatan IAEA "The Safety of Nuclear Installations". Kewajibankewajiban itu mencakup misalnya tapak, desain, konstruksi, operasi, ketersediaan finansial dan sumber daya manusia, pengkajian dan verifikasi keselamatan, jaminan mutu dan kesiapsiagaan kedaruratan. Konvensi merupakan suatu instrumen pendorong, yang tidak dirancang untuk menjamin pemenuhan kewajiban-kewajiban oleh Negara Pihak melalui kontrol dan sanksi namun didasarkan pada kepentingan bersama untuk mencapai tingkattingkat keselamatan yang lebih tinggi yang akan dikembangkan dan dipromosikan melalui pertemuan-pertemuan regular Para Pihak. Konvensi mewajibkan Para Pihak untuk menyampaikan laporan-laporan tentang implementasi kewajiban untuk 'penilaian kelompok ahli (peer review)' dalam pertemuan-pertemuan Para Pihak yang diselenggarakan di IAEA. Mekanisme ini merupakan elemen inovatif yang utama dan dinamis dari Konvensi.

Konvensi Gabungan tentang Keselamatan Pengelolaan Bahan Bakar Bekas dan Keselamatan Pengelolaan Limbah Radioaktif (The Joint Convention on the Safety of Spent Fuel Management and the Safety of Radioactive Waste Management) menjadi instrumen internasional pertama yang mengatur masalah keselamatan manajemen dan penyimpanan limbah radioaktif di negara-negara baik yang mempunyai program nuklir maupun yang tidak. Konvensi ini secara signifikan memperluas rezim keselamatan nuklir IAEA dan mempromosikan standar-standar Internasional untuk mengelola suatu isu yang menjadi kepedulian utama masyarakat. Konvensi berlaku pada keselamatan manajemen bahan bakar 
bekas, didefinisikan sebagai "semua aktivitas yang berhubungan dengan penanganan atau penyimpanan bahan bakar bekas." Juga berlaku pada keselamatan manajemen radioaktif, didefinisikan sebagai "semua kegiatan, termasuk kegiatan dekomisioning, yang berhubungan dengan penanganan, pra-treatment, treatment, conditioning, penyimpanan, atau pembuangan limbah radioaktif'. Konvensi juga mencakup keselamatan manajemen bahan bakar bekas atau limbah radioaktif yang berasal dari program militer atau pertahanan jika dan ketika material-material tersebut ditransfer secara permanen dan dikelola di dalam program-program sipil eksklusif, atau ketika dinyatakan sebagai bahan bakar bekas atau limbah radioaktif.

Salah satu tujuan Konvensi, adalah untuk menjamin bahwa selama semua tahap dari manajemen bahan bakar bekas dan limbah radioaktif ada suatu cara pertahanan efektif terhadap bahaya potensial sedemikian hingga semua individu, masyarakat dan lingkungan terlindungi dari efek-efek berbahaya radiasi pengion, sekarang dan nanti.

Konvensi menetapkan suatu sistem pelaporan yang mengikat bagi Negara Pihak untuk mengatur semua langkah-langkah yang diambil oleh masing-masing negara untuk mengimplementasikan kewajiban-kewajiban di bawah Konvensi, termasuk pelaporan keberadaan timbunan-timbunan limbah radioaktif dan bahan bakar bekas secara nasional.

\section{Pemberitahuan Dini dan Bantuan Kedaruratan}

Belajar dari peristiwa Chernobyl telah ditetapkan dua konvensi kembar, yaitu Konvensi Pemberitahuan Dini Terjadinya Kecelakaan Nuklir (Convention on Early Notification of a Nuclear Accident) dan Konvensi Pemberian Bantuan dalam Hal Terjadinya Kecelakaan Nuklir atau Kedaruratan Radiologis (Convention on Assistance in the Case of Nuclear Accident or Radiological Emergency). Yang disebutkan pertama menetapkan suatu sistem pemberitahuan dini atas terjadinya kecelakaan nuklir yang mempunyai potensi pelepasan bahanbahan radioaktif yang melintasi batas-batas Internasional antar negara yang mempunyai dampak keselamatan radiologis bagi Negara lain. Konvensi mewajibkan Negara yang mengalami kecelakaan nuklir untuk melaporkan waktu, lokasi, tingkat pelepasan radiasi, dan data esensial lainnya guna keperluan pengkajian situasi. Pemberitahuan diberikan kepada Negara-negara yang bakal terkena dampak yang dapat disampaikan secara langsung atau melalui IAEA, dan kepada IAEA itu sendiri. Pelaporan adalah wajib bagi setiap kecelakaan nuklir yang meliputi fasilitas dan aktivitas berikut: setiap reaktor nuklir di manapun berada; setiap fasilitas daur bahan bakar nuklir; setiap fasilitas pengelolaan limbah radioaktif; transportasi dan penyimpanan bahan bakar nuklir atau limbah radioaktif; manufaktur, penggunaan, penyimpanan, pembuangan dan transportasi radioisotop bagi keperluan pertanian, industri, kedokteran, dan penelitian serta ilmiah yang terkait; dan penggunaan radioisotop untuk pembangkitan daya di wahanawahana ruang angkasa. Pemberitahuan dan Informasi juga harus diberikan dalam hal terjadi kecelakaan nuklir selain yang dinyatakan di atas, guna meminimalkan konsekuensi-konsekuensi radiologis.

Sementara yang disebutkan terakhir menetapkan suatu kerangka kerja internasional bagi kerja sama di antara Negara-negara Pihak dan dengan IAEA untuk memfasilitasi bantuan dan dukungan segera dalam peristiwa kecelakaan nuklir ataupun kedaruratan nuklir. Negara-Negara Pihak wajib memberitahu IAEA tentang ketersediaan ahli (expert), perlengkapan, dan bahan-bahan lain yang mereka miliki guna pemberian bantuan. Atas permintaan, tiap Negara Pihak memutuskan apakah ia dapat menyumbang bantuan yang diminta juga lingkup dan syarat-syaratnya. Bantuan dapat ditawarkan tanpa biaya yang diperhitungkan antara lain keperluan negara-negara berkembang dan khususnya keperluan negara-negara tanpa fasilitas nuklir. IAEA bertindak sebagai pusat koordinasi (focal point) bagi kerja sama tersebut dengan cara meneruskan/menyalurkan informasi, usaha-usaha bantuan/dukungan, dan memberikan jasa-jasa yang ada.

\section{Keamanan Nuklir}

\section{Konvensi Proteksi Fisik}

Tujuan untuk mencapai tingkat keselamatan nuklir yang tinggi harus digandakan dengan tujuan mencapai tingkat keamanan nuklir yang tinggi juga. Keamanan nuklir harus diperkuat dengan pengembangan dan penerapan langkah-langkah yang memadai dalam proteksi fisik terhadap pencurian atau penyimpangan bahan nuklir dan terhadap sabotase fasilitas nuklir. Proteksi fisik merupakan hal yang menjadi perhatian nasional dan internasional sejak lama, dan kepatuhan yang menyeluruh pada Konvensi Proteksi Fisik Bahan Nuklir (Convention on the Physical Protection of Nuclear Material) memberi bukti kesungguhan negara-negara menerima kewajiban internasional di bidang ini. Penguatan terhadap keamanan nuklir menjadi fokus setelah keruntuhan Uni Soviet, ketika terjadi sejumlah kasus penyeludupan bahan nuklir dan munculnya kegiatan terorisme internasional, seperti peristiwa 11 September 2001. Ini menekankan perlunya penguatan rezim internasional keamanan nuklir, dengan membangun budaya keamanan sebagai aspek utama. 
Konvensi mewajibkan Negara-negara Pihak untuk menjamin selama transportasi nuklir internasional memberikan proteksi bahan nuklir di dalam wilayah teritorial mereka atau di atas kapalkapal mereka atau pesawat-pesawat udara mereka.

Konvensi tersebut memberikan suatu kerangka kerja yang sangat sesuai bagi kerja sama internasional dalam perlindungan (proteksi), pemulihan dan pengembalian bahan nuklir yang hilang/tercuri dan dalam penerapan sanksi pidana terhadap orang-orang yang melakukan tindakan kriminal yang melibatkan bahan nuklir.

\section{Terorisme Nuklir}

Isu terbaru di bidang keamanan nuklir adalah keprihatinan tentang kemungkinan penggunaan bahan radioaktif atau nuklir untuk tujuan terorisme. Potensi untuk menggunakan bahan peledak konvensional untuk menyebarkan bahan radioaktif, apa yang disebut "bom kotor (dirty bomb)", menekankan pentingnya kontrol nasional dan internasional terhadap bahan-bahan tersebut. IAEA telah bekerja untuk membangun kerangka kerja internasional untuk meningkatkan keamanan sumber radioaktif.

Payung internasional untuk penanggulangan ancaman terorisme nuklir berhasil dicapai melalui penetapan Konvensi Penanggulangan Tindakan Terorisme Nuklir (the International Convention on the Suppression of Acts of Nuclear Terrorism) oleh MU PBB di New York pada 13 April 2005.

\section{Sistem Seifgard (Safeguard)}

\section{Traktat Non-Proliferasi Senjata Nuklir}

Sejak 1960-an, sistem seifgard (pengawasan) internasional IAEA merupakan komponen sentral dalam mengontrol penyebaran senjata nuklir. Di bawah ketentuan-ketentuan dari persetujuanpersetujuan yang dicapai IAEA dengan negaranegara penandatangan, para inspektur (pengawas) IAEA secara teratur mengunjungi fasilitas-fasilitas nuklir untuk memverifikasi rekaman-rekaman yang dilakukan otorita negara bersangkutan tempat di mana bahan nuklir berada, mencek peralatan dan perlengkapan seifgard yang dipasang IAEA, dan mengkonfirmasi penyimpanan fisik bahan-bahan nuklir. Mereka kemudian membuat laporan-laporan rinci kepada negara yang ditinjau dan kepada IAEA.

Seifgard merupakan peraturan teknis verifikasi yang sesuai dengan kewajiban-kewajiban legal yang relevan dengan penggunaan nuklir tujuan damai. Tujuannya adalah politis, yaitu untuk menjamin masyarakat internasional tentang sifat damai kegiatan nuklir yang diseifgard dan untuk mencegah penyimpangan atau penyalahgunaan bahan-bahan atau fasilitas-fasilitas yang diseifgard melalui deteksi dini.

Persetujuan-persetujuan legal merupakan basis seifgard IAEA, yang antara lain secara popular banyak dikenal sebagai persetujuanpersetujuan skop-penuh (full-scope agreements) karena mencakup pada semua aktivitas dan bahanbahan nuklir tujuan damai di negara terkait. Ini terkait dengan Traktat Non-Proliferasi Senjata Nuklir (NPT).

Traktat Non-Proliferasi Senjata Nuklir (Treaty on the Non-Proliferation of Nuclear Weapons-NPT) merupakan traktat internasional yang bertujuan untuk mencegah penyebaran senjata nuklir dan teknologi senjata nuklir, mendorong perkembangan penggunaan energi nuklir untuk maksud damai, dan memajukan tujuan mencapai perlucutan secara umum dan menyeluruh. Traktat menetapkan suatu sistem seifgard (safeguards system) di bawah tanggung jawab IAEA.

\section{Kontrol pada Bahan Nuklir}

Seifgard IAEA merupakan sarana kunci untuk mendeteksi dan menghalangi pengalihan bahan nuklir oleh suatu Negara. Semua negara tidak bersenjata nuklir yang menjadi pihak NPT harus menyetujui penerapan seifgard IAEA ke semua bahan nuklir mereka. Perjanjian seifgard yang komprehensif atau lingkup penuh dimaksudkan untuk memberikan keyakinan bahwa negara tidak bersenjata nuklir senantiasa bertindak sesuai dengan komitmennya untuk tidak memproduksi senjata nuklir. Pada tahun 1997, sebuah protokol tambahan pada seifgard (Additional Protocol to Safeguard$A P)$, yang meliputi cara-cara untuk meningkatkan kemampuan untuk mendeteksi aktivitas nuklir yang mungkin tidak dilaporkan, telah disetujui.

Inti dari seifgard adalah deklarasi negara tentang bahan, fasilitas dan kegiatan nuklir digabungkan dengan pemeriksaan IAEA atau akses untuk memverifikasi informasi ini. Pemeriksaan biasanya dilakukan secara acak, namun ada pemberitahuan awal setidaknya setiap tahun. Dalam fasilitas yang paling sensitif bahkan pemeriksaan fisik dapat dilakukan terus menerus.

Kegiatan inspeksi IAEA dapat mencakup verifikasi bahwa desain fasilitas nuklir adalah seperti dinyatakan, pemeriksaan catatan operasi, pengukuran dan sampling dari bahan nuklir itu sendiri, dan penggunaan peralatan seifgard dan penyegelan perangkat untuk mempertahankan pengetahuan material. Protokol tambahan seifgard mensyaratkan bahwa Negara-negara memberikan informasi lebih luas mengenai kegiatan nuklir mereka (meluas kepada orang-orang yang belum tentu melibatkan bahan nuklir) dan memungkinkan akses IAEA ke semua lokasi yang bersangkutan atas dasar dadakan atau undangan.

Selain itu, langkah-langkah keamanan nasional digunakan untuk mencegah pencurian atau 
pengalihan bahan nuklir dan teknologi serta untuk mencegah sabotase. Langkah-langkah keamanan sebagian besar terdiri dari kontrol keamanan fisik seperti fasilitas yang aman, penjaga bersenjata, kunci khusus dan kode akses dan kamera, termasuk juga kontrol organisasi seperti membatasi akses ke informasi sensitif dan pemeriksaan keamanan individu.

\section{Kontrol pada Teknologi Kunci}

Bahan dan teknologi kunci tertentu dikenakan kontrol ekspor internasional yang sangat ketat karena sangat penting untuk memastikan bahwa mereka tidak diselewengkan untuk tujuan militer.

Grup Pemasok Nuklir (Nuclear Supplier Group--NSG) memiliki serangkaian pedoman pemasokan nuklir yang mengatur pengalihan bahan dan teknologi kunci. Pedoman transfer bahan nuklir, peralatan, teknologi, komponen dan fasilitas didefinisikan dalam daftar item ekspor. Anggota NSG sepakat untuk tidak mentransfer item yang terdapat dalam daftar tersebut kepada negara tidak bersenjata nuklir yang tidak memiliki perjanjian seifgard komprehensif (Comprehensive Safeguards Agreement--CSA) dengan IAEA. NSG juga memiliki pedoman yang terkait dengan perpindahan tertentu item atau teknologi dwiguna yang dapat digunakan untuk militer, seperti komputer berkecepatan tinggi.

Demikian pula, negara pihak pada NPT bekerja sama untuk mengontrol teknologi misil (rudal) yang dapat membawa senjata nuklir melalui Rezim Kontrol Teknologi Misil (MTCR). Tindakan juga diambil untuk menghentikan penyelundupan bahan nuklir.

\section{Kontrol pada Uji Coba Senjata Nuklir}

Perundingan pada larangan uji coba menyeluruh senjata nuklir dicapai dengan diadopsinya CTBT pada September 1996. Traktat melarang semua uji coba ledakan nuklir, baik untuk tujuan militer atau sipil. Para negara penandatangan setuju untuk melarang atau mencegah ledakan nuklir di setiap tempat di dalam yurisdiksi mereka atau mengendalikan, dan tidak mendorong dengan cara partisipasi dalam setiap ledakan nuklir. Traktat ini menciptakan sebuah rezim verifikasi yang komprehensif termasuk melakukan pemeriksaan di tempat, ketentuan konsultasi dan klarifikasi, dan saling membangun kepercayaan tindakan. Pemberlakuan Traktat ini menunggu ratifikasi ke 44 negara yang memiliki reaktor nuklir. Indonesia saat ini sedang melakukan langkah-langkah proses ratifikasi. Peratifikasian ini diharapkan akan membantu meningkatkan kepercayaan publik, khususnya dunia internasional, terhadap program nuklir Indonesia.

\section{Pertanggungjawaban Kerugian Nuklir}

Sebagian besar negara telah mengadopsi undang-undang pertanggungjawaban (liabilitas) dan kompensasi untuk menjamin mereka yang mengalami kerugian sebagai akibat kecelakaan nuklir.

Di bawah rezim ini, operator instalansi nuklir adalah bertanggung jawab atas kerugian nuklir yang diderita oleh pihak ketiga sebagai akibat kecelakaan nuklir yang terjadi di instalasi nuklir atau melibatkan zat yang berasal dari instalasi itu. Operator instalasi nuklir juga diwajibkan untuk menjaga keamanan keuangan yang mencakup jumlah pertanggungjawaban untuk memastikan bahwa dana selalu tersedia untuk mengkompensasi kerugiaan yang diderita. Meskipun keamanan keuangan ini dapat diperoleh melalui berbagai cara, misalnya garansi bank, penjaminan aktiva, jaminan negara atau melalui bentuk asuransi negara, dalam prakteknya, asuransi swasta adalah bentuk paling umum untuk keamanan finansial.

Mengingat risiko dan jumlah cakupan yang diperlukan besar, tidak mungkin bagi perusahaan asuransi individu untuk mengasuransikan risiko ini sendiri. Akibatnya, asuransi nuklir disediakan oleh "pool", sebuah grup perusahaan asuransi yang bergabung pada basis asuransi bersama. Sejak dibentuk di pertengahan 1950-an, kapasitas pool tersebut telah meningkat berkali-kali, tidak hanya karena makin banyak perusahaan yang bergabung, tapi juga karena meningkatnya pengalaman, mereka mampu menanggung risiko lebih.

Namun demikian, meskipun dengan penyatuan sumberdaya, total kapasitas keuangan mereka biasanya masih kurang dari jumlah jaminan keuangan yang dibutuhkan operator PLTN.

Akibatnya, pool nasional bekerja dengan pool nasional lainnya untuk mendapatkan cakupan untuk keseimbangan. Secara umum, pool nasional berkomitmen mensponsori untuk memberikan nilai asuransi penuh kepada nasabah dan kemudian mengansuransikan kembali (reinsurence) sebagian besar jumlah tersebut melalui kontrak reasuransi dengan pool lain.

Hal ini diakui bahwa jumlah pertanggungjawaban operator mungkin tidak cukup untuk mencakup konsekuensi kecelakaan nuklir. Oleh karena itu, melengkapi persyaratan keamanan keuangan, sebagian besar negara, misalnya negaranegara OECD, memiliki mekanisme atau kebijakan untuk memberikan bantuan keuangan tambahan atau kompensasi dari dana publik dalam hal keamanan finansial operator tidak cukup untuk mengimbangi kerugian yang terjadi. Langkahlangkah khusus dan jumlahnya bervariasi dari satu negara ke negara lain.

Selain rezim kompensasi nasional ini, banyak negara penandatangan atau pihak pada salah satu dari beberapa konvensi internasional yang 
menetapkan pertanggungjawaban dan rezim kompensasi untuk mengelola proses tuntutan kompensasi kecelakaan nuklir yang rumit dengan efek transnasional.

Pada saat peristiwa Chernobyl, Vienna Convention on Civil Liability for Nuclear Damage 1963 (Konvensi Wina tentang Pertanggungjawaban Perdata Kerugian Nuklir) telah berlaku sejak 1977 dan Paris Convention 1960/1964/1982 berlaku sejak 1968 dan 1985. Namun kedua rezim pertanggungjawaban tersebut tidak dapat digunakan untuk memberi kompesasi pada para korban. Uni Soviet bukan negara pihak pada salah satu konvensi, dan belum mempunyai legislasi pertanggungjawaban nuklir nasionalnya. Hikmah yang didapat dari peristiwa itu adalah bahwa menetapkan rezim hukum pertanggungjawaban nuklir tidaklah cukup. Perlu usaha-usaha politis tambahan untuk meyakinkan negara-negara untuk mengadopsinya. Hingga saat ini masih tampak bahwa negara-negara belum sepenuhnya memahami pelajaran ini karena rezim pertanggungjawaban nuklir global belumlah tercapai secara penuh.

Peristiwa kecelakaan tidak hanya berdampak di negara bersangkutan, tapi juga pada negara tetangga bahkan yang lebih jauh, sehingga memicu pembicaraan tentang kepantasan skema pertanggungjawaban nuklir yang ada.

Setelah peristiwa Chernobyl, IAEA memprakarsai pekerjaan pada semua aspek pertanggungjawaban nuklir dengan suatu pandangan untuk menyempurnakan Konvensikonvensi dasar dan menetapkan suatu rezim pertanggungjawaban yang komprehensif. Pada 1988, sebagai hasil usaha bersama IAEA dan OECD/NEA, sebuah Protokol Gabungan yang Menghubungkan Aplikasi Konvensi Wina dan Konvensi Paris (the Joint Protocol Relating to the Application of the Vienna Convention and the Paris Convention) berhasil diadopsi. Protokol Gabungan menetapkan suatu hubungan (link) antara Konvensikonvensi tersebut yang menggabungkan mereka kedalam satu rezim pertanggungjawaban yang diperluas. Pihak pada Protokol Gabungan diperlakukan seakan-akan mereka adalah Pihak pada kedua Konvensi dan pilihan aturan hukum disediakan untuk menentukan yang mana dari dua Konvensi tersebut yang harus berlaku dengan mengenyampingkan yang lain dalam hal kecelakaan yang sama.

Dalam periode dari 1988 hingga 2004, perundingan-perundingan berlangsung untuk mempertimbangkan pengalaman Chernobyl dan untuk memperkuat hukum pertanggungjawaban nuklir internasional. Dimulai dengan perumusan dan pengadopsian the Joint Protocol Relating in the Application of the Vienna Convention and the Paris Convention, dilanjutkan dengan perumusan dan pengadopsian Revision Protocol to the Vienna
Convention dan Convention on Supplementary Compensation dari 1989 hingga 1997 di Wina, serta perumusan dan pengadopsian Revision Protocols to the Paris Convention dan Brussels Supplementary Convention dari 1998 hingga 2004 di Paris.

Dalam bulan September 1997, pemerintah mengambil langkah maju yang sangat berarti dalam penyempurnaan rezim pertanggungjawaban kerugian nuklir. Pada Konferensi Diplomatik di Markas Besar IAEA, Wina, 8-12 September 1997, delegasi dari lebih 80 negara mengadopsi Protocol to Amend the 1963 Vienna Convention on Civil Liability for Nuclear Damage (Protokol untuk Amandemen Konvensi Wina 1963 tentang Pertanggungjawaban Perdata Kerugian Nuklir) dan juga mengadopsi Convention on Supplementary Compensation for Nuclear Damage (Konvensi tentang Kompensasi Pelengkap untuk Kerugian Nuklir). Protokol menetapkan batas ganti rugi yang mungkin oleh operator tidak kurang dari 300 juta SDR (Special Drawing Right) (kurang lebih setara dengan 400 juta dollar Amerika). Sementara Konvensi tentang Kompensasi Pelengkap untuk Kerugian Nuklir menetapkan jumlah tambahan yang harus disediakan melalui kontribusi Negaranegara Pihak yang didasarkan pada kapasitas nuklir terpasang dan nilai kajian PBB.

Konvensi merupakan suatu instrumen terhadap semua negara harus mematuhinya tanpa memandang apakah mereka merupakan negara pihak pada konvensi pertanggungjawaban nuklir yang ada atau mempunyai instalasi nuklir di dalam wilayah kedaulatan mereka atau tidak. Protokol mengandung antara lain suatu definisi yang lebih baik tentang kerugian nuklir (kini juga mencakup konsep kerusakan lingkungan dan langkah-langkah pencegahan), memperluas cakupan geografis Konvensi Wina, dan memperpanjang periode lamanya klaim dapat dilakukan atas kehilangan jiwa dan cacat yang diderita.

Konvensi juga melengkapi yurisdiksi negara-negara pantai terhadap tindakan-tindakan yang mendatangkan kerugian nuklir selama transportasi. Dilakukan secara bersama, kedua instrumen tersebut secara substansial hendaknya memperkuat kerangka kerja global terhadap kompensasi lebih baik dari yang diatur oleh Konvensi-konvensi sebelumnya.

Sebelum aksi September 1997, rezim pertanggungjawaban internasional diatur terutama dalam dua instrumen, yaitu: Konvensi Wina 1963 dan Konvensi Paris 1960 yang disatukan oleh Protokol Gabungan (the Joint Protocol) yang diadopsi pada 1988. Konvensi Paris kelak diperkuat dengan Konvensi Brussels 1963 tentang Pelengkap (the 1963 Brussels Supplementary Convention). Konvensi-konvensi ini didasarkan pada konsep hukum perdata dan menganut prinsip-prinsip utama berikut, antara lain: 
1. Pertanggungjawaban secara ekslusif dibebankan pada operator instalasi nuklir.

2. Pertanggungjawaban operator adalah mutlak, yaitu operator harus menanggung pertanggungjawaban tanpa memandang bagaimana kesalahan terjadi.

3. Pertanggungjawaban adalah terbatas dalam jumlah.

4. Pertanggungjawaban adalah terbatas dalam waktu.

5. Operator harus menjaminkan suatu asuransi.

6. Yurisdiksi atas tindakan secara eksklusif berada pada pengadilan Negara Pihak yang mempunyai wilayah di mana kecelakaan nuklir terjadi.

7. Non-diskriminasi korban atas dasar kebangsaan, domisili, dan tempat tinggal.

\section{KERANGKA PERATURAN PERUNDANG-UNDANGAN}

\section{Kerangka Legislatif}

Kerangka instrumen perjanjian internasional (diberikan dalam Tabel 2) seperti yang diuraikan di atas selanjutnya menjadi pedoman dalam penyusunan kerangka peraturan perundangundangan pada level nasional, yang diperlukan sebagai infrastuktur penting pada program PLTN.

Kerangka peraturan perundang-undangan menetapkan tugas dan tanggung jawab dari berbagai organisasi yang diperlukan program PLTN. Ini mencakup kerangka kerja legislatif dan kerangka peraturan. Legislasi nasional harus mencakup, secara komprehensif, semua aspek hukum nuklir, yaitu keselamatan, keamanan, seifgard (pengawasan) dan pertanggungjawaban kerugian nuklir. Setiap negara yang mempertimbangkan program nuklir harus memiliki infrastruktur hukum nasional mengenai radiasi, limbah dan keselamatan transportasi yang sesuai dengan standar internasional dan mencakup semua kegiatan, praktek dan fasilitas.

Sebagai bidang khusus hukum nuklir sangat membutuhkan masukan dari para ahli profesional dalam merumuskan undang-undang yang benar dan sesuai. Namun, undang-undang harus konsisten dengan tradisi hukum dan politik nasional, institusi, keadaan ekonomi, tingkat perkembangan teknologi dan nilai-nilai budaya. Undang-undang adalah harus yang pertama ditegakkan dalam upaya pengembangan program nuklir.

Unsur-unsur dasar yang harus dilakukan meliputi antara lain:

1. Legislasi yang berurusan dengan kebijakan energi nasional, pertimbangan ekonomi dan komersial, dengan penetapan yang jelas lembaga atau badan yang bertanggung jawab, termasuk hubungan mereka dengan tenaga nuklir;
2. Legislasi yang berurusan dengan pembentukan badan regulator independen yang berwenang pada sistem perizinan, inspeksi dan penegakan hukum dan termasuk semua subjek hukum nuklir, yaitu proteksi radiasi, bahan radioaktif dan sumber radiasi, keamanan instalasi nuklir, kesiapsiagaan kedaruratan dan tindakan tanggap darurat, pertambangan dan penggilingan, transportasi, limbah radioaktif dan bahan bakar bekas, pertanggungjawaban kerugian nuklir dan kompesasi, proteksi, kontrol ekspor dan impor, dan proteksi fisik.

3. Legislasi investasi asing, termasuk peran perusahaan asing, vendor dan pemasok, dan hak kekayaan intelektual;

4. Legislasi yang berhubungan dengan peran pemerintah nasional, pemerintah daerah, pemangku kepentingan dan publik;

5. Legislasi yang berhubungan dengan masalah daur bahan bakar dan kepemilikan bahan nuklir;

6. Pengembangan sumber daya manusia untuk memastikan integritas lebih lanjut program nuklir;

7. Komitmen untuk menggunakan tenaga nuklir hanya untuk tujuan damai.

Kerangka perjanjian internasional ketenaganukliran meliputi semua aspek yang dicakup dalam hukum nuklir, seperti disajikan dalam tabel berikut.

\section{Table 2. Instrumen Internasional Relevan}

\begin{tabular}{|c|}
\hline $\begin{array}{l}\text { Comprehensive Safeguards Agreement } \\
\text { (INFCIRC/153 Corr.) }\end{array}$ \\
\hline $\begin{array}{l}\text { Additional Protocol pursuant to INFCIRC/540 } \\
\text { (Corr.) }\end{array}$ \\
\hline $\begin{array}{l}\text { Convention on Early Notification of a Nuclear } \\
\text { Accident (INFCIRC/335) }\end{array}$ \\
\hline $\begin{array}{l}\text { Convention on Assistance in the Case of a Nuclear } \\
\text { Accident or Radiological Emergency } \\
\text { (INFCIRC/336) }\end{array}$ \\
\hline Convention on Nuclear Safety (INFCIRC/449) \\
\hline $\begin{array}{l}\text { Joint Convention on the Safety of Spent Fuel } \\
\text { Management and on the Safety of }\end{array}$ \\
\hline $\begin{array}{l}\text { Radioactive Waste Management (the 'Joint } \\
\text { Convention'), INFCIRC/546 }\end{array}$ \\
\hline $\begin{array}{l}\text { Convention on the Physical Protection of Nuclear } \\
\text { Material (INFCIR/274) dan Amendmentnya }\end{array}$ \\
\hline $\begin{array}{l}\text { Vienna Convention on Civil Liability for Nuclear } \\
\text { Damage (INFCIRC/500) }\end{array}$ \\
\hline $\begin{array}{l}\text { Joint Protocol Relating to the Application of the } \\
\text { Vienna Convention and the Paris Convention, } \\
\text { INFCIRC/402 }\end{array}$ \\
\hline $\begin{array}{l}\text { Protocol to Amend the } 1963 \text { Vienna Convention on } \\
\text { Civil Liability for Nuclear Damage }\end{array}$ \\
\hline $\begin{array}{l}\text { Convention on Supplementary Compensation for } \\
\text { Nuclear Damage }\end{array}$ \\
\hline $\begin{array}{l}\text { Revised Supplementary Agreement concerning the } \\
\text { provision of Technical Assistance by the IAEA }\end{array}$ \\
\hline
\end{tabular}


Perundang-undangan nasional diperlukan agar sesuai dengan usaha non-proliferasi yang menyatakan tanggung jawab keselamatan, keamanan dan seifgard harus ditetapkan secara jelas.

Legislasi menetapkan tanggung jawab dan pertanggungjawaban yang jelas bagi pengoperasian fasilitas nuklir dan penanganan dan seifgard bahan nuklir.

\section{Kerangka Peraturan}

Kerangka peraturan untuk mendukung sepenuhnya program nuklir sangat luas. Beberapa negara biasanya memulai proses tersebut dengan mengadopsi peraturan pemerintah negara pemasok PLTN pertama, sebagai pendekatan yang dapat diterima, asalkan konsisten dengan hukum yang telah ditetapkan. Namun, dari waktu ke waktu dapat disesuaikan dengan kondisi dan budaya setempat. meliputi:

Elemen-elemen dasar kerangka peraturan

1. Pembentukan badan pengawas independen dengan kewenangan yang jelas dan sumber daya manusia dan keuangan yang memadai;

2. Penetapan tugas fungsi pengaturan bagi pengembangan peraturan, perizinan, review dan penilaian, inspeksi, penegakan dan informasi publik;

3. Otoritas untuk memperoleh dukungan teknis yang diperlukan;

4. Penetapan hubungan yang jelas antara badan pengawas dengan organisasi lain;

5. Penetapan hak dan tanggung jawab pemegang lisensi;

6. Otoritas untuk melaksanakan kewajiban internasional, termasuk seifgard IAEA;

7. Otoritas untuk terlibat dalam kerjasama internasional;

8. Ketentuan untuk melindungi kepemilikan, informasi rahasia dan keamanan;

9. Ketentuan untuk pemangku kepentingan dan informasi publik dan interaksi;

10. Kompatibilitas dengan kerangka peraturan yang ada untuk radiasi, limbah dan keselamatan transportasi.

Perundang-undangan yang dikembangkan dalam kerangka legislatif akan membentuk badan pengawas independen yang tepat secara efektif dan lingkup kewenangan. Setelah persyaratan hukum terpenuhi badan pengawas segera dibentuk dan diberdayakan sesuai dengan undang-undang.

Mekanisme dibentuk untuk komunikasi terbuka dengan pemilik/organisasi operator. Mekanisme tersebut bersifat transparan sehingga independensi badan pengawas jelas. Fokus selalu berada pada pertimbangan keselamatan. Seluruh proses perizinan harus dikembangkan dan dipublikasikan sehingga jelas bagi seluruh pemangku kepentingan. Kriteria peraturan untuk penerimaan dan persetujuan desain PLTN harus ditentukan sebelum penerbitan tawaran pengadaan.

Pada tahap perkembangan ini, isu-isu prioritas penting adalah:

1. Organisasi, staf dan pelatihan;

2. Seifgard;

3. Keamanan;

4. Transportasi, penanganan dan penyimpanan bahan nuklir dan bahan radioaktif;

5. Proteksi radiasi;

6. Proses perizinan;

7. Peraturan, kode dan standar untuk penentuan tapak, desain, konstruksi, dan operasi yang diperlukan untuk pemberian lisensi PLTN, termasuk sistem manajemen;

8. Kesiapsiagaan kedaruratan (tapak, luar tapak dan nasional);

9. Pembentukan hubungan internasional dengan badan-badan yang berwenang lainnya;

10. Manajemen limbah, termasuk rencana penyimpanan lestari.

\section{Keselamatan Nuklir}

Keselamatan nuklir memerlukan komitmen semua unsur, yaitu pemerintah, operator, pengatur, vendor dan organisasi lainnya, dalam promosi dan pencapaian keselamatan, menyiapkan dan melaksanakan program tenaga nuklir. Semua masalah dalam penyiapan infrastruktur nuklir memiliki dampak pada keselamatan.

Ketika memulai program nuklir, negara terkait akan menjadi mitra dari sebuah rezim keaselamatan nuklir global yang didedikasikan untuk menjaga keselamatan nuklir di seluruh dunia. Menjadi mitra yang bertanggung jawab memberikan manfaat pada jaringan kerjasama internasional dalam keselamatan nuklir. Sebagai bagian dari kerjasama ini adalah memastikan bahwa program yang dilaksanakan konsisten dengan Prinsip Dasar Keselamatan IAEA dan standar keselamatan IAEA lainnya, atau yang setara.

Pengalaman menunjukkan bahwa ketergantungan pada sistem keselamatan rekayasa saja, dengan sendirinya, tidak cukup untuk menjamin keselamatan nuklir. Pelajaran penting adalah bahwa operasi yang aman dan selamat hanya dapat dijamin jika ada infrastruktur yang memastikan bahwa persyaratan spesifik teknologi nuklir tertentu diakui dan kondisi yang tepat ditetapkan untuk menanganinya secara aman.

Peraturan keselamatan dan seifgard harus disiapkan guna proses perizinan PLTN yang menyertakan pemilihan dan evaluasi tapak, konstruksi, komisioning, operasi komersial, dekomisioning dan pengelolaan bahan bakar bekas dan limbah radioaktif. 
Hal-hal berikut mengenai beberapa isu keselamatan, yang diambil dari pengalaman negara lain, yang penting dalam membangun PLTN pertama di suatu negara:

1. Keterampilan dan sikap operator. Operator PLTN memiliki tanggung jawab pertama dan utama untuk menjamin keselamatan;

2. Sistem manajemen. Sistem manajemen fasilitas dan kegiatan nuklir yang berhubungan secara koheren dengan keselamatan, kesehatan, lingkungan, keamanan, mutu dan persyaratan ekonomi sepanjang usia fasilitas dan untuk seluruh durasi kegiatan normal, situasi sementara dan darurat harus ditetapkan.

3. Budaya keamanan. Harus dinilai dan dipertahankan selama usia reaktor.

4. Kerangka hukum. Meskipun jaminan keselamatan berada pada operator, namun suatu struktur hukum sebagai landasan diperlukan.

5. Independensi, kompetensi dan otoritas pengatur. Sama seperti halnya bagi operator yang harus memiliki staf berpengalaman, pengatur juga harus memiliki staf yang kompeten dan memiliki dukungan akses yang semestinya.

6. Kompetensi teknis. Perlunya staf dengan keterampilan untuk melakukan operasi, regulasi dan pemeliharaan seluruh program nuklir secara berkelanjutan.

7. Stabilitas keuangan. Penelitian menunjukkan bahwa tenaga nuklir akan kompetitif dengan teknologi pembangkit lainnya, terutama dengan munculnya isu emisi karbon. Untuk mempertahankan keselamatan, dukungan keuangan yang memadai pada seluruh dan setelah masa operasi sangat diperlukan.

8. Kesiapsiagaan kedaruratan. Perlu untuk tidak hanya mengambil langkah-langkah untuk menjamin operasi yang aman, tetapi juga untuk mempersiapkan kemungkinan adanya kegagalan dan keadaan kedaruratan nuklir.

9. Konektivitas international. Merupakan bidang antarmuka untuk dukungan dari seluruh dunia.

\section{Penanganan Limbah Radioaktif}

Penanganan dan pembuangan limbah radioaktif merupakan isu paling penting dalam pemanfaatan nuklir. Limbah radioaktif perlu dikelola sedemikian rupa untuk menghindarkan beban berlebihan pada generasi mendatang. Untuk itu, generasi yang menghasilkan limbah tersebut harus mencari dan menerapkan solusi yang aman, praktis dan ramah lingkungan untuk pengelolaan jangka panjang. Dalam keadaan tertentu, pengelolaan bahan bakar bekas dan limbah radioaktif yang aman dan efisien mungkin dapat dibangun melalui kesepakatan antara negara-negara untuk menggunakan fasilitas yang ada di salah satu dari mereka untuk kepentingan yang lain.
Limbah radioaktif umumnya diperlakukan berdasarkan tiga tingkatan: rendah, menengah dan tinggi. Kemampuan manajemen limbah tingkat rendah dan menengah (LILW) telah tercipta dengan baik ndalam kaitannya dengan kesehatan, keselamatan dan aplikasi penelitian, dalam rangka infrastruktur nasional untuk radiasi, transportasi dan limbah. Beberapa negara telah mengembangkan kemampuan untuk pembuangan limbah tersebut. Kemampuan manajemen pembuangan limbah tingkat tinggi juga sedang dikembangkan oleh semua negara yang memiliki PLTN.

Program dan teknologi untuk minimisasi dan pengolahan LILW telah dikembangkan dan berhasil diterapkan di banyak negara. Meskipun telah terdapat konsep untuk pembuangan akhir dari bahan bakar bekas atau HLW, fasilitas pembuangan belum dibangun. Telah ditunjukkan kemampuan untuk menyimpan bahan bakar bekas yang aman selama puluhan tahun, tetapi perlu waktu untuk pengembangan strategi penyimpanan lestari bahan bakar bekas atau HLW. Namun demikian, strategi ini hendaknya diperhitungkan lebih awal dalam pengembangan program nuklir karena penyimpanan lestari limbah adalah subyek yang menjadi perhatian masyarakat umum. Strategi yang dipertimbangkan saat ini adalah penyimpanan lestari dalam formasi geologi baik bahan bakar bekas dan/atau sisa HLW setelah pengolahan ulang bahan bakar bekas. Penelitian sedang berlangsung untuk memperkecil volume dan toksisitas HLW melalui berbagai proses seperti transmutasi nuklir.

Pengakuan yang jelas tentang tanggung jawab terhadap limbah radioaktif program nuklir sangat dibutuhkan.

Pertimbangan utama meliputi:

1. Pengetahuan tentang kemampuan nasional yang ada, kerangka peraturan dan pengalaman penanganan limbah radioaktif, penyimpanan sementara, dan penyimpanan lestari;

2. Pengetahuan tentang volume dan kandungan isotop LILW dari fasilitas nuklir;

3. Pengetahuan tentang pilihan yang ada untuk penyimpanan jangka panjang bahan bakar bekas;

4. Pengetahuan tentang pilihan dan penelitian untuk penyimpanan lestari dari bahan bakar bekas atau HLW;

5. Organisasi dan pembiayaan untuk bahan bakar bekas dan pengelolaan limbah radioaktif.

Pengetahuan tentang kemampuan pembuangan limbah menunjukkan pengakuan atas komitmen terkait nuklir. Selain itu, menjadi pihak pada Konvensi Gabungan akan menyediakan sarana untuk saling belajar dalam komunitas ilmiah global. 


\section{Jurnal Forum Nuklir (JFN), Volume 6, Nomor 1, Mei 2012}

\section{Rencana Kesiapsiagaan Kedaruratan}

PLTN dirancang dan dioperasikan dengan perhatian penuh pada keselamatan. Desain sistem keselamatan meminimalkan kemungkinan pelepasan radiasi ke lingkungan. Namun, probabilitas kecelakaan tidak nol. Dua kecelakaan paling serius, Three Mile Island dan Chernobyl, menunjukkan bahwa perencanaan kedaruratan guna melindungi personil reaktor, pekerja darurat dan masyarakat di luar tapak merupakan elemen penting keselamatan PLTN secara keseluruhan dan memberikan tingkat pertahanan tambahan secara mendalam.

Untuk itu, sebagai persyaratan program nuklir harus dikembangkan suatu perencanaan kedaruratan. Sedangkan kebutuhan perencanaan kedaruratan ditetapkan oleh badan pengawas sesuai dengan hukum nasional, dan tanggung jawab pelaksanaan oleh pemilik/operator, perlu melibatkan pemerintah setempat dan nasional. Tempat berlindung darurat atau evakuasi publik dapat direkomendasikan oleh pemilik/operator, tetapi kewenangan untuk memerintahkan mereka tetap pada pemerintah setempat. Ketentuan perlindungan publik dalam perencanaan kedaruratan harus dikomunikasikan sebagai bagian dari informasi publik.

Pendekatan rinci untuk perencanaan kedaruratan dimulai pada saat penentuan pemilihan lokasi. Rencana kesiapsiagaan kedaruratan harus mempertimbangkan baik PLTN maupun masyarakat sekitar. Masalah penting ini meliputi:

1. Pengembangan rencana kedaruratan;

2. Penilaian ancaman;

3. Perumusan rencana tanggap darurat dan konsep operasi;

4. Perumusan prosedur untuk melindungi pekerja darurat;

5. Pengkajian karakteristik demografi tapak yang dipilih sebagai bagian dari evaluasi dan perizinan tapak;

6. Prosedur untuk ketentuan pemberitahuan kepada publik, informasi dan instruksi dimasukkan sebagai bagian dari persiapan tapak;

7. Pertimbangan pendekatan untuk berlindung dan evakuasi masyarakat dan identifikasi setiap hambatan;

8. Perumusan prosedur untuk tindakan medis;

9. Prosedur untuk perlindungan jangka panjang segera dan lingkungan hidup telah dirumuskan;

10. Prosedur untuk menangani konsekuensi nonradiologi telah dipertimbangkan;

11. Perjanjian partisipasi otoritas setempat dan nasional.

Menetapkan kondisi untuk mempersiapkan pelaksanaan yang efektif dari perencanaan darurat akan memberikan keyakinan pada saat operasi PLTN. Apresiasi terhadap pentingnya perencanaan darurat dan perjanjian pada alokasi peran dari pemilik/operator dan otoritas pemerintah serta keanggotaan pada konvensi pemberitahuan awal kecelakaan nuklir dan bantuan dalam kasus kecelakaan nuklir atau radiologi darurat menunjukkan pengakuan atas komitmen pada perencanaan kedaruratan.

\section{Keamanan dan Proteksi Fisik}

Keamanan dan proteksi fisik dimaksudkan untuk mencegah tindakan berbahaya dari pihakpihak yang tidak bertanggungjawab di dalam atau di luar fasilitas dan tapak yang dapat membahayakan publik atau lingkungan. Program keamanan dan proteksi fisik untuk PLTN dan fasilitas lainnya, bahan nuklir, bahan bakar, dan transportasi limbah radioaktif, dan penyimpanan harus tersedia setiap saat. Keamanan nuklir memerlukan upaya dan komitmen dari semua pihak yang terlibat dalam perencanaan, perancangan, pembangunan dan pengoperasian PLTN. Agar efektif, sangat penting bagi organisasi-organisasi untuk mengakui pentingnya keamanan nuklir dan menerapkan budaya keamanan nuklir.

Hukum mengatur otoritas keamanan nuklir dan sanksi pidana bagi setiap pelanggaran yang dilakukan. Staf keamanan yang selalu berada di tempat diperlukan sebagai pencegahan tingkat pertama. Perjanjian dengan pemerintah setempat dan nasional untuk menambah staf bantuan memberikan pencegahan tingkat kedua. Program seleksi staf secara hati-hati dan kualifikasi untuk akses ke fasilitas nuklir atau bahan membantu untuk memastikan tidak adanya ancaman internal atau eksternal. Rencana keamanan dan prosedur harus dikoordinasikan secara seksama dengan persyaratan keselamatan nuklir sehingga tidak mengakibatkan peningkatan risiko kepada publik.

Adalah penting adanya komitmen untuk selalu berusaha mencegah tindakan berbahaya yang akan membahayakan masyarakat, dan sekaligus dampaknya pada masyarakat internasional.

Oleh karena itu, komitmen mengupayakan budaya keamanan yang sungguh-sungguh harus ditetapkan sebelum membuat komitmen untuk melancurkan program nuklir.

Pengakuan persyaratan keamanan dan proteksi fisik dan identifikasi perundang-undangan memberikan pengakuan terhadap komitmen tersebut.

Hal-hal yang perlu diperhatikan meliputi:

1. Penetapan peraturan perundang-undangan tentang keamanan dan proteksi fisik;

2. Perumusan persyaratan keamanan dan fitur yang diinginkan untuk tapak, tata letak dan desain PLTN telah dirumuskan;

3. Penetapan protokol dan program untuk bantuan penegakan hukum lokal dan nasional; 
4. Program untuk definisi informasi sensitif, persyaratan proteksi dan hukuman terkait;

5. Pemberlakuan hukum yang memberikan hukuman untuk tindakan berbahaya, kepemilikan ilegal dan perdagangan bahan nuklir, seperti dijelaskan dalam instrumen internasional;

6. Program untuk seleksi yang seksama dan kualifikasi staf program nuklir dengan akses ke fasilitas atau informasi sensitif;

7. Penetapan program untuk mengembangkan design basis threat (DBT);

8. Design sistem proteksi fisik untuk melindungi target dari DBT;

9. Pengembangan proteksi fisik untuk transportasi dan penyimpanan bahan nuklir dan limbah.

\section{Seifgard}

Negara tidak bersenjata nuklir yang menjadi pihak pada NPT harus melakukan CSA dengan IAEA sesuai INFCIRC/153 (Corrected). Juga perjanjian Protokol Tambahan (AP) berdasarkan INFCIR/540 (Corrected), menyediakan pelaksanaan penguatan sistem seifgard IAEA. CSA bersamasama dengan AP berisi kewajiban tertentu yang dilakukan oleh negara untuk menerima seifgard, dan hak-hak yang diperlukan dan alat bagi IAEA untuk melaksanakan seifgard (pengawasan) dalam rangka memberikan keyakinan yang kredibel bahwa negara itu memenuhi kewajibannya berdasarkan NPT untuk penggunaan damai energi nuklir secara eksklusif. Pelaksanaan seifgard diterapkan sesuai untuk bahan nuklir dan kegiatan dalam negara atau di mana pun di bawah kontrol atau yurisdiksi negara bersangkutan.

Dalam rangka menjalankan kontrol negara yang diperlukan dan untuk memfasilitasi kerjasama dengan IAEA dalam melaksanakan ketentuan CSA dan AP, negara harus menetapkan dan memelihara SSAC yang memadai. Ini merupakan kewajiban di bawah CSA tentang jumlah bahan nuklir atau tingkat aplikasi nuklir di negara tersebut. Pembentukan SSAC adalah untuk melayani suatu tujuan yang berguna, yaitu, untuk memastikan pelaksanaan yang efektif dari seifgard yang diterapkan. Dalam hal ini, pengakuan terhadap kebutuhan untuk menerapkan faktor-faktor berikut dianggap penting saat menyelenggarakan seifgard dalam negara:

1. Kerjasama antara negara, operator fasilitas dan IAEA dalam pelaksanaan seifgard;

2. Kecukupan SSAC dalam hubungannya dengan persyaratan IAEA untuk akuntansi dan pengendalian bahan nuklir;

3. Kemampuan IAEA untuk secara independen memverifikasi kelengkapan dan kebenaran deklarasi negara, yang telah dilaporkan sesuai dengan perjanjian seifgardnya.
Suatu negara harus memberikan informasi awal kepada IAEA pada rencana yang terkait dengan daur bahan bakar nuklir, usaha penelitian, lokasi di mana bahan nuklir dapat digunakan, dan ekspor dan impor bahan dan item yang tunduk pada instrumen seifgard yang relevan. Pedoman dan pelatihan telah dikembangkan oleh IAEA, yang tersedia untuk membantu negara dalam hal ini.

Tergantung pada keputusan kebijakan yang dilakukan oleh negara dalam rangka mendukung peningkatan infrastruktur tenaga nuklir dan sifat perundang-undangan di negara, aturan dan peraturan yang ada, negara mungkin perlu mempersiapkan undang-undang khusus perlindungan yang relevan, aturan, peraturan dan prosedur. Misalnya, ketika negara berencana mengembangkan/memanfaatkan bahan nuklir dan teknologi nuklir, kontrol ekspor-impor mungkin perlu disesuaikan atau dibangun, dan diterapkan secara efektif sesuai dengan hukum/peraturan nasional. Dalam hal ini, organisasi dan program bagi pelaksanaan yang efektif dan penegakan hukum tersebut harus direncanakan, dan kepastian status ini diperlukan sebelum mengajukan penawaran PLTN pertama.

\section{KESIAPAN INFRASTRUKTUR PERATURAN PERUNDANG-UNDANGAN NUKLIR NASIONAL}

\section{Proses Legislasi Nuklir}

Proses pembuatan peraturan atau merevisi kerangka hukum nasional untuk pengembangan dan penggunaan teknologi nuklir dan penggunaan bahan nuklir secara signifikan tidak berbeda dari proses pembuatan hukum di bidang kepentingan nasional lain. Undang-undang tenaga nuklir, seperti undangundang lainnya, harus memenuhi persyaratan konstitusional dan kelembagaan masing-masing negara sesuai sistem politik dan hukum. Namun, masalah energi nuklir sangat kompleks dan teknis, dengan beberapa kegiatan dan bahan-bahan yang menimbulkan risiko yang tidak biasa bagi kesehatan manusia, keselamatan dan lingkungan, dan juga risiko keamanan nasional dan internasional. Akibatnya, suatu bangunan sangat rinci dan kompleks mengenai unsur-unsur teknis harus diurai untuk memastikan bahwa kegiatan yang berhubungan dengan nuklir dapat dilakukan dengan cara yang aman, selamat dan ramah lingkungan. Unsur-unsur teknis terdiri dari prinsip-prinsip umum, persyaratan atau aturan wajib, pedoman yang tidak mengikat atau rekomendasi dan praktek informal. Mereka mencakup berbagai bidang teknis, dari PLTN hingga penggunaan sumber radioaktif tertutup di kedokteran, industri dan pertanian. Selain itu, menumbuhkan struktur kewajiban traktat internasional dan menerima aturan 'praktek terbaik' 
akan menyediakan peluang bagi pemerintah untuk menyelaraskan hukum mereka dengan hukum negara lain, sehingga memberikan kontribusi untuk penanganan lebih efisien dan konsisten tentang halhal yang menjadi perhatian komunitas global.

Dihadapkan dengan spektrum aturan teknis yang luas, bagaimana seharusnya pendekatan legislasi untuk membuat aturan teknis yang mengikat pihak-pihak yang terlibat dalam penggunaan energi nuklir, termasuk perorangan, perusahaan komersial swasta, institusi akademik, organisasi profesional dan lembaga pemerintah. Jelas tidak diinginkan untuk memasukkan meskipun hanya sejumlah kecil aturan teknis ke dalam hukum nasional. Melakukan itu akan menghasilkan naskah yang sangat panjang, tidak dapat dipahami oleh orang-orang. Juga, mungkin menghambat kemajuan keselamatan kerja yang berkaitan dengan kemajuan ilmu pengetahuan, teknologi, manajemen dan regulasi. Selain itu, aturan teknis tidak selalu harus berlaku umum, mereka mungkin hanya berlaku untuk suatu aktivitas atau fasilitas tertentu, dengan penyesuaian berdasarkan karakteristik dan risiko tertentu. Sebagai praktek yang baik dalam menyusun undang-undang, hukum biasanya harus dibingkai sedemikian rupa untuk mencerminkan persyaratan yang berlaku umum yang mencakup bidang kepentingan umum yang luas.

Singkatnya, langkah-langkah teknis untuk keselamatan, keamanan dan proteksi lingkungan hidup di bidang nuklir harus mengambil bentuk: Prinsip dasar diterapkan sebagai hukum yang berlaku umum dan mengikat semua orang dan organisasi; dan Persyaratan teknis (termasuk peraturan, pedoman dan rekomendasi) yang tidak berlaku umum dan dibuat mengikat orang-orang tertentu atau organisasi oleh pihak otoritas atau melalui syarat perizinan tertentu, mengikat hanya pada pemegang lisensi.

\section{Pengkajian dan Perencanaan Program Nuklir}

Apakah suatu negara adalah menciptakan suatu kerangka untuk perundang-undangan nuklir atau merevisi kerangka yang ada, atau hanya memperbarui satu aspek dari undang-undang nuklirnya, langkah pertama dalam proses tersebut harus melakukan pengkajian terhadap program saat ini dan yang diharapkan serta rencana yang melibatkan penggunaan teknik dan bahan nuklir.

Apapun badan yang dibebankan untuk melakukan pengkajian, badan tersebut harus memahami program tersebut dan mempertimbangkan program yang dapat muncul pada beberapa waktu pada iklim ekonomi global yang berubah cepat. Adalah selalu lebih baik untuk memberikan pedoman legislatif di awal pada bidang tertentu tentang bagaimana aktivitas terkait nuklir harus diatur daripada membiarkannya tanpa persyaratan peraturan. Untuk tujuan praktis, penyusun undang-undang harus membuat pengaturan regulasi nasional untuk kegiatan terkait nuklir dalam lingkup yang luas.

Selain itu, tidak cukup hanya menilai alternatif atau pilihan yang mungkin menarik. Pemerintah harus siap membuat keputusan tegas dalam lingkup dan karakter jenis pengembangan energi nuklir yang mereka inginkan. Keputusan ini membutuhkan pernyataan kebijakan nasional yang jelas, sesuatu yang mungkin melibatkan perdebatan panjang dan penyesuaian pandangan. Beberapa kegiatan dapat menghasilkan keterlibatan politik yang besar, sementara yang lain mungkin sama sekali tidak kontroversial.

\section{Persiapan Indonesia}

Dalam rangka mempersiapkan infrastruktur legislatif dan peraturan untuk program PLTN, Indonesia telah melakukan berbagai penataan, baik dalam hal kelembagaan maupun dalam penyusunan peraturan perundang-undangan yang berlaku. Revisi terhadap Undang-undang Pokok-pokok Tenaga Atom No. 31 tahun 1964 dengan Undang-undang No 10 tahun 1997 tentang Ketenaganukliran mencerminkan usaha-usaha tersebut.

Selain itu sesuai dengan rekomendasi IAEA melalui Konvensi Keselamatan Nuklir tahun 1994 dan Basic Safety Standard No. 115 tahun 1996, Indonesia telah melakukan pemisahan antara badan pengatur dan badan pelaksana agar pemanfaatan nuklir berjalan efektif dan untuk menghindari perbenturan kepentingan.

Pemerintah Indonesia juga telah, dan akan terus, melakukan tahapan proses harmonisasi dan transformasi standar-standar internasional ke dalam peraturan perundang-undangan nasional sesuai prinsip-prinsip yang diuraikan di atas. Hal ini dapat dilihat dari telah dikeluarkannya sejumlah peraturan seperti Peraturan Pemerintah No. 63 tahun 2000 tentang Kesehatan dan Keselamatan terhadap Pemanfaatan Radiasi Pengion, Peraturan Pemerintah No. 64 tahun 2000 tentang Perizinan Pemanfaatan Tenaga Nuklir, Peraturan Pemerintah Nomor 26 Tahun 2002 tentang Keselamatan Pengangkutan Zat Radioaktif, Peraturan Pemerintah No. 27 tahun 2002 tentang Pengelolaan Limbah Radiaoktif, Peraturan Pemerintah Nomor 43 Tahun 2006 tentang Perizinan Reaktor Nuklir, Peraturan Pemerintah Nomor 33 Tahun 2007 tentang Keselamatan Radiasi Pengion dan Keamanan Sumber Radioaktif, Peraturan Pemerintah Nomor 29 Tahun 2008 tentang Perizinan Pemanfaatan Sumber Radiasi Pengion Dan Bahan Nuklir, Peraturan Pemerintah Nomor 46 Tahun 2009 tentang Batas Pertanggungjawaban Kerugian Nuklir. 
Peraturan Pemerintah tersebut selanjutnya dijabarkan oleh Badan Pengawas Tenaga Nuklir (BAPETEN), sebagai badan regulator, yang diwujudkan dalam bentuk peraturan Kepala BAPETEN.

Peraturan perundang-undangan yang dikeluarkan telah hampir mencakup semua aspek hukum nuklir: Keselamatan, Keamanan, Seifgard dan Pertanggungjawaban Kerugian Nuklir. Peraturan perundang-undangan yang dikeluarkan selengkapnya disajikan dalam Lampiran 1.

\section{PENUTUP}

Program PLTN adalah sebuah upaya yang membutuhkan perencanaan, investasi dan persiapan sumber daya manusia, yang harus didasarkan pada komitmen untuk menggunakan tenaga nuklir hanya untuk tujuan damai, dengan cara yang aman dan selamat, dengan penyiapan suatu infrastruktur nasional yang berkelanjutan yang melibatkan aspek pemerintahan, peraturan perundang-undangan, manajerial, teknologi, sumber daya manusia dan industri sepanjang siklus program tersebut.

Unjuk kepatuhan terhadap instrumen hukum internasional, standar keselamatan nuklir yang diterima secara internasional, panduan keamanan nuklir dan persyaratan seifgard (safeguard) sangat penting dalam membangun program nuklir yang bertanggung jawab.

Peraturan perundang-undangan adalah yang pertama harus ditegakkan dalam upaya pengembangan program nuklir, yang mencakup pembentukan badan regulator independen yang berwenang pada sistem perizinan, inspeksi dan penegakan hukum dan termasuk semua subjek hukum nuklir, yaitu proteksi radiasi, bahan radioaktif dan sumber radiasi, keamanan instalasi nuklir, kesiapsiagaan kedaruratan dan tindakan tanggap darurat, pertambangan dan penggilingan, transportasi, limbah radioaktif dan bahan bakar bekas, pertanggungjawaban kerugian nuklir dan kompesasi, proteksi, kontrol ekspor dan impor, dan proteksi fisik.

Dalam rangka program PLTN, Pemerintah telah menerbitkan berbagai peraturan perundangundangan yang mencakup semua aspek hukum nuklir dan mengacu pada konvensi dan standar internasional.

Dengan perundangan-undangan ketenaganukliran, masyarakat akan merasa aman dan tenteram dan penggunaan nuklir di berbagai bidang tidak perlu dikhawatirkankan karena peraturan perundangan mengharuskan pemakai mengikuti aturan-aturan yang ada supaya pekerja, masyarakat maupun lingkungan hidup terhindar dari bahaya radiasi.

\section{DAFTAR PUSTAKA}

1. FISCHER, DAVID, History of the International Atomic Energy Agency: the first forty years, Vienna: The Agency, 1997

2. International Atomic Energy Agency, Milestones in the Development of a National Infrastructure for Nuclear Power, IAEA Nuclear Energy Series No. NG-G-3.1, IAEA, Vienna, 2007

3. International Atomic Energy Agency, Fundamental Safety Principles, IAEA Safety Standard for protecting people and the environment Series No. SF-1, IAEA, Vienna, 2006

4. PELZER, NORBERT, Learning the Hard Way: Did the Lessons Taugt by the Chernobyl Nuclear Accident Contribute to Improving Nuclear Law? dalam A Joint Report by the OECD Nuclear Energy Agency and the IAEA: the International Nuclear Law in Post-Chernobyl Period, Paris, OECD NEA, 2006;

5. RAUTENBACH, JOHAN, et al., Overview of the International Legal Framework Governing in the Safe and Peaceful Uses of Nuclear EnergySome Pratical Steps, dalam A Joint Report by the OECD Nuclear Energy Agency and the IAEA: the International Nuclear Law in PostChernobyl Period, Paris, OECD NEA, 2006;

6. STOIBER, CARLTON, et al., Handbook of Nuclear Law, Vienna: The Agency, 2003

7. STOIBER, CARLTON, et al., Handbook of Nuclear Law: Implementing Legislation, Vienna: The Agency, 2010 


\section{Lampiran 1}

\section{PRODUK HUKUM DAN PERATURAN PERUNDANG-UNDANGAN KETENAGANUKLIRAN}

\section{Undang-Undang}

Undang Undang Nomor 8 Tahun 1978 tentang Pengesahan Perjanjian mengenai Pencegahan Penyebaran Senjata-senjata Nuklir

(1) Undang Undang Negara Republik Indonesia Nomor 9 Tahun 1997 tentang Pengesahan Treaty on the Southeast Asia Nuclear Weapon Free Zone (Traktat Kawasan Bebas Senjata Nuklir di Asia Tenggara)

(2) Undang Undang Nomor 10 Tahun 1997 tentang Ketenaganukliran

\section{Peraturan Pemerintah}

(1) Peraturan Pemerintah Nomor 26 Tahun 2002 tentang Keselamatan Pengangkutan Zat Radioaktif

(2) Peraturan Pemerintah Nomor 27 Tahun 2002 tentang Pengelolaan Limbah Radioaktif

(3) Peraturan Pemerintah Nomor 43 Tahun 2006 tentang Perizinan Reaktor Nuklir

(4) Peraturan Pemerintah Nomor 33 Tahun 2007 tentang Keselamatan Radiasi Pengion dan Keamanan Sumber Radioaktif

(5) Peraturan Pemerintah Nomor 29 Tahun 2008 tentang Perizinan Pemanfaatan Sumber Radiasi Pengion Dan Bahan Nuklir

(6) Peraturan Pemerintah Nomor 46 Tahun 2009 tentang Batas Pertanggungjawaban Kerugian Nuklir

\section{Peraturan Presiden}

(1) Peraturan Presiden Nomor 49 Tahun 1986 tentang Pengesahan Convention On The Physical Protection Of Nuclear Material

(2) Peraturan Presiden Nomor 80 Tahun 1993 tentang Pengesahan An Amandement Of Article VI Of The Statue Of The International Atomic Energy Agency

(3) Peraturan Presiden Nomor 81 Tahun 1993tentang Pengesahan Convention On Early Notification Of A Nuclear Accident

(4) Peraturan Presiden Nomor 82 Tahun 1993 tentang Pengesahan Convention On Assistance In The Case Of A Nuclear Accident Or Radiology Emergency

(5) Peraturan Presiden Nomor 106 Tahun 2001 tentang Pengesahan Convention On Nuclear Safety (Konvensi Tentang Keselamatan Nuklir)
(6) Peraturan Presiden Nomor 46 Tahun 2009 tentang Pengesahan Amendment to The Convention on The Physical Protection of Nuclear Material (Perubahan Konvensi Proteksi Fisik Bahan Nuklir)

\section{Peraturan Kepala BAPETEN:}

\section{KESELAMATAN}

\section{Proteksi dan Keselamatan Radiasi}

(1) Peraturan Kepala BAPETEN Nomor 01/Ka-BAPETEN/V-99 tentang Ketentuan Keselamatan Kerja Terhadap Radiasi

(2) Peraturan Kepala BAPETEN Nomor 02/Ka-BAPETEN/V-99 tentang Baku Tingkat Radioaktivitas di Lingkungan

(3) Peraturan Kepala BAPETEN Nomor 11/Ka-BAPETEN/VI-99 tentang Izin Konstruksi dan Operasi Iradiator

(4) Peraturan Kepala BAPETEN Nomor 12/Ka-BAPETEN/VI-99 tentang

Ketentuan Keselamatan Kerja Penambangan dan Pengolahan Bahan Galian Radioaktif

(5) Peraturan Kepala BAPETEN Nomor 14/Ka-BAPETEN/VI-99 tentang Ketentuan Keselamatan Pabrik Kaos Lampu

(6) Peraturan Kepala BAPETEN Nomor 07P/Ka-BAPETEN/I-02 tentang Pedoman Dekomisioning Fasilitas Medis, Industri dan Penelitian serta Instalasi Nuklir NonReaktor

(7) Peraturan Pemerintah Nomor 26 Tahun 2002 tentang Keselamatan Pengangkutan Zat Radioaktif

(8) Peraturan Pemerintah Nomor 27 Tahun 2002 tentang Pengelolaan Limbah Radioaktif

(9) Peraturan Kepala BAPETEN Nomor 21/Ka-BAPETEN/XII-02 tentang Program Jaminan Kualitas Instalasi Radioterapi

(10) Peraturan Kepala BAPETEN Nomor 01-P /Ka-BAPETEN/ I-03 tentang Pedoman Dosis Pasien Radiodiagnostik

(11) Peraturan Kepala BAPETEN Nomor 02P/Ka-BAPETEN/I-03 tentang Sistem Pelayanan Pemantauan Dosis Eksterna Perorangan

(12) Peraturan Kepala BAPETEN Nomor 1 Tahun 2006 tentang Laboratorium Dosimetri, Kalibrasi Alat Ukur Radiasi Dan Keluaran Sumber Radiasi Terapi, Dan Standardisasi Radionuklida

(13) Peraturan Pemerintah Nomor 43 Tahun 2006 tentang Per izinan Reaktor Nuklir

(14) Undang Undang Nomor 10 Tahun 1997 tentang Ketenaganukliran 
(15) Peraturan Pemerintah Nomor 33 Tahun 2007 tentang Keselamatan Radiasi Pengion dan Keamanan Sumber Radioaktif

(16) Peraturan Pemerintah Nomor 29 Tahun 2008 tentang Perizinan Pemanfaatan Sumber Radiasi Pengion Dan Bahan Nuklir

(17) Peraturan Kepala BAPETEN Nomor 5 Tahun 2009 tentang Keselamatan Radiasi Dalam Penggunaan Zat Radioaktif Untuk Well Logging

(18) Peraturan Kepala BAPETEN Nomor 6 Tahun 2009 tentang Keselamatan Radiasi Dalam Penggunaan Zat Radioaktif Dan Pesawat Sinar-X Untuk Peralatan Gauging

(19) Peraturan Kepala BAPETEN Nomor 7 Tahun 2009 Keselamatan Radiasi Dalam Penggunaan Peralatan Radiografi Industri

(20) Peraturan Kepala BAPETEN Nomor 9 Tahun 2009 tentang Intervensi Terhadap Paparan Yang Berasal Dari Technologically Enhanced Naturally Occurring Radioactive Material

(21) Peraturan Presiden Nomor 46 Tahun 2009 tentang Pengesahan Amendment to The Convention on The Physical Protection of Nuclear Material (Perubahan Konvensi Proteksi Fisik Bahan Nuklir)

(22) Peraturan Kepala BAPETEN Nomor NOMOR 3 TAHUN 2010 tentang Desain Sistem Penanganan dan Penyimpanan Bahan Bakar Nuklir untuk Reaktor Daya

\section{Keselamatan Nuklir}

(1) Peraturan Kepala BAPETEN Nomor 05/Ka-Bapeten/V-99 tentang Ketentuan Keselamatan Disain Reaktor Penelitian

(2) Peraturan Kepala BAPETEN Nomor 06/Ka-BAPETEN/V-99 tentang Pembangunan dan Pengoperasian Reaktor Nuklir

(3) Peraturan Kepala BAPETEN Nomor 07/Ka-BAPETEN/V-99 tentang Jaminan Kualitas Instalasi Nuklir

(4) Peraturan Kepala BAPETEN Nomor 01P/Ka-BAPETEN/VI-99 tentang Pedoman Penentuan Tapak Reaktor Nuklir

(5) Peraturan Kepala BAPETEN Nomor 03P/Ka-BAPETEN/VI-99 tentang Pedoman Teknis Penyusunan Analisis Mengenai Dampak Lingkungan Untuk Rencana Pembangunan dan Pengoperasian Reaktor Nuklir

(6) Peraturan Kepala BAPETEN Nomor 04P/Ka-BAPETEN/VI-99 tentang Pedoman Teknis Penyusunan Analisis Mengenai Dampak Lingkungan Untuk Rencana
Pembangunan dan Pengoperasian Instalasi Nuklir dan Instalasi Lainnya

(7) Peraturan Kepala BAPETEN Nomor 10/Ka-BAPETEN/VI-99 tentang Ketentuan Keselamatan Operasi Reaktor Penelitian

(8) Peraturan Kepala BAPETEN Nomor 06-P /Ka-BAPETEN/XI-00 tentang Pedoman Pembuatan Laporan Analisis Keselamatan

(9) Peraturan Kepala BAPETEN Nomor 07P/Ka-BAPETEN/I-02 tentang Pedoman Dekomisioning Fasilitas Medis, Industri dan Penelitian serta Instalasi Nuklir NonReaktor

(10) Peraturan Kepala BAPETEN Nomor 05P/Ka-BAPETEN/I-03 tentang Pedoman Rencana Penanggulangan Keadaan Darurat

(11) Peraturan Kepala BAPETEN Nomor 3 Tahun 2006 tentang Perizinan Instalasi Nuklir Nonreaktor

(12) Peraturan Kepala BAPETEN Nomor 10 Tahun 2006 tentang Pedoman Penyusunan Laporan Analisis Keselamatan Instalasi Nuklir Nonreaktor

(13) Peraturan Pemerintah Nomor 43 Tahun 2006 tentang Perizinan Reaktor Nuklir

(14) Undang Undang Nomor 10 Tahun 1997 tentang Ketenaganukliran

(15) Peraturan Kepala BAPETEN Nomor 5 Tahun 2007 tentang Ketentuan Keselamatan Evaluasi Tapak Reaktor Nuklir

(16) Peraturan Kepala BAPETEN Nomor 11 Tahun 2007 tentang Ketentuan Keselamatan Instalasi Nuklir Non Reaktor

(17) Peraturan Kepala BAPETEN Nomor 14 Tahun 2007 tentang Satuan Tanggap Darurat

(18) Peraturan Kepala BAPETEN Nomor 1 Tahun 2008 tentang Evaluasi Tapak Reaktor Daya Untuk Aspek Kegempaan

(19) Peraturan Kepala BAPETEN Nomor 2 Tahun 2008 tentang Evaluasi Tapak Reaktor Daya Untuk Aspek Kegunungapian

(20) Peraturan Kepala BAPETEN Nomor 3 Tahun 2008 tentang Evaluasi Tapak Reaktor Daya Untuk Aspek Penentuan Dispersi Zat Radioaktif di Udara dan Air, dan Pertimbangan Distribusi Penduduk Di Sekitar Tapak Reaktor Daya

(21) Peraturan Kepala BAPETEN Nomor 4 Tahun 2008 tentang Evaluasi Tapak Reaktor Daya Untuk Aspek Geoteknik Dan Pondasi Reaktor Daya

(23) Peraturan Kepala BAPETEN Nomor 5 Tahun 2008 tentang Evaluasi Tapak Reaktor Daya Untuk Aspek Meteorologi 
(24) Peraturan Kepala BAPETEN Nomor 6 Tahun 2008 tentang Evaluasi Tapak Reaktor Daya Untuk Aspek Kejadian Eksternal Akibat Ulah Manusia

(25) Peraturan Kepala BAPETEN Nomor 8 Tahun 2008 tentang Ketentuan Keselamatan Manajemen Penuaan Reaktor NonDaya

(26) Peraturan Pemerintah Nomor 29 Tahun 2008 tentang Perizinan Pemanfaatan Sumber Radiasi Pengion Dan Bahan Nuklir

(27) Peraturan Kepala BAPETEN Nomor 2 Tahun 2009 tentang Penyusunan Daftar Informasi Desain

(28) Peraturan Pemerintah Nomor 27 Tahun 2009 tentang Jenis Dan Tarif Atas Jenis Penerimaan Negara Bukan Pajak Yang Berlaku Pada Badan Pengawas Tenaga Nuklir

(29) Peraturan Kepala BAPETEN Nomor 9 Tahun 2009 tentang Intervensi Terhadap Paparan Yang Berasal Dari Technologically Enhanced Naturally Occurring Radioactive Material

(30) Peraturan Kepala BAPETEN Nomor NOMOR 3 TAHUN 2010 tentang Desain Sistem Penanganan dan Penyimpanan Bahan Bakar Nuklir untuk Reaktor Daya

\section{Pengangkutan Zat Radioaktif}

(1) Peraturan Kepala BAPETEN Nomor 04/Ka-BAPETEN/V-99 tentang Ketentuan Keselamatan Untuk Pengangkutan Zat Radioaktif

(2) Peraturan Kepala BAPETEN Nomor 05P/Ka-BAPETEN/VII-00 tentang Pedoman Persyaratan Untuk Keselamatan Pengangkutan Zat Radioaktif

(3) Peraturan Pemerintah Nomor 26 Tahun 2002 tentang Keselamatan Pengangkutan Zat Radioaktif

(4) Peraturan Pemerintah Nomor 27 Tahun 2002 tentang Pengelolaan Limbah Radioaktif

(5) Peraturan Kepala BAPETEN Nomor 03P/Ka-BAPETEN/ I- 03 tentang Persyaratan Laboratorium Uji Bungkusan Zat Radioaktif Tipe A Dan Tipe B

(6) Undang Undang Nomor 10 Tahun 1997 tentang Ketenaganukliran

(7) Peraturan Pemerintah Nomor 33 Tahun 2007 tentang Keselamatan Radiasi Pengion dan Keamanan Sumber Radioaktif

(8) Peraturan Pemerintah Nomor 29 Tahun 2008 tentang Perizinan Pemanfaatan Sumber Radiasi Pengion Dan Bahan Nuklir
(9) Peraturan Pemerintah Nomor 27 Tahun 2009 tentang Jenis Dan Tarif Atas Jenis Penerimaan Negara Bukan Pajak Yang Berlaku Pada Badan Pengawas Tenaga Nuklir

(10) Peraturan Kepala BAPETEN Nomor NOMOR 3 TAHUN 2010 tentang Desain Sistem Penanganan dan Penyimpanan Bahan Bakar Nuklir untuk Reaktor Daya

\section{Pengelolaan Limbah Radioaktif}

(1) Peraturan Kepala BAPETEN Nomor 03/Ka-BAPETEN/V-99 tentang Ketentuan Keselamatan Untuk Pengelolaan Limbah Radioaktif

(2) Peraturan Pemerintah Nomor 27 Tahun 2002 tentang Pengelolaan Limbah Radioaktif

(3) Peraturan Pemerintah Nomor 43 Tahun 2006 tentang Perizinan Reaktor Nuklir

(4) Undang Undang Nomor 10 Tahun 1997 tentang Ketenaganukliran

(5) Peraturan Pemerintah Nomor 33 Tahun 2007 tentang Keselamatan Radiasi Pengion dan Keamanan Sumber Radioaktif

(6) Peraturan Pemerintah Nomor 29 Tahun 2008tentang Perizinan Pemanfaatan Sumber Radiasi Pengion Dan Bahan Nuklir

(7) Peraturan Pemerintah Nomor 27 Tahun 2009 tentang Jenis Dan Tarif Atas Jenis Penerimaan Negara Bukan Pajak Yang Berlaku Pada Badan Pengawas Tenaga Nuklir

(8) Peraturan Kepala BAPETEN Nomor NOMOR 3 TAHUN 2010 tentang Desain Sistem Penanganan dan Penyimpanan Bahan Bakar Nuklir untuk Reaktor Daya

\section{Kesiapsiagaan Nuklir}

(1) Peraturan Pemerintah Nomor 43 Tahun 2006 tentang Perizinan Reaktor Nuklir

(2) Undang Undang Nomor 10 Tahun 1997 tentang Ketenaganukliran

(3) Peraturan Pemerintah Nomor 29 Tahun 2008 tentang Perizinan Pemanfaatan Sumber Radiasi Pengion Dan Bahan Nuklir

(4) Peraturan Pemerintah Nomor 27 Tahun 2009 tentang Jenis Dan Tarif Atas Jenis Penerimaan Negara Bukan Pajak Yang Berlaku Pada Badan Pengawas Tenaga Nuklir

(5) Peraturan Kepala BAPETEN Nomor NOMOR 3 TAHUN 2010 tentang Desain Sistem Penanganan dan Penyimpanan Bahan Bakar Nuklir untuk Reaktor Daya 


\section{KEAMANAN}

Keamanan Sumber Radioaktif

(1) Undang Undang Nomor 10 Tahun 1997 tentang Ketenaganukliran

(2) Peraturan Pemerintah Nomor 33 Tahun 2007 tentang Keselamatan Radiasi Pengion dan Keamanan Sumber Radioaktif

(3) Peraturan Kepala BAPETEN Nomor 7 Tahun 2007 tentang Keamanan Sumber Radioaktif

(4) Peraturan Pemerintah Nomor 29 Tahun 2008 tentang Perizinan Pemanfaatan Sumber Radiasi Pengion Dan Bahan Nuklir

(5) Peraturan Kepala BAPETEN Nomor NOMOR 3 TAHUN 2010 tentang Desain Sistem Penanganan dan Penyimpanan Bahan Bakar Nuklir untuk Reaktor Daya

\section{Proteksi Fisik Instalasi Dan Bahan Nuklir}

(1) Peraturan Pemerintah Nomor 26 Tahun 2002 tentang Keselamatan Pengangkutan Zat Radioaktif

(2) Peraturan Pemerintah Nomor 27 Tahun 2002 tentang Pengelolaan Limbah Radioaktif

(3) Peraturan Pemerintah Nomor 43 Tahun 2006 tentang Perizinan Reaktor Nuklir

(4) Undang Undang Nomor 10 Tahun 1997 tentang Ketenaganukliran

(5) Peraturan Pemerintah Nomor 29 Tahun 2008 tentang Perizinan Pemanfaatan Sumber Radiasi Pengion Dan Bahan Nuklir

(6) Peraturan Kepala BAPETEN Nomor 1 Tahun 2009 tentang Ketentuan Sistem Proteksi Fisik Instalasi dan Bahan Nuklir

(7) Peraturan Presiden Nomor 46 Tahun 2009 tentang Pengesahan Amendment to The Convention on The Physical Protection of Nuclear Material (Perubahan Konvensi Proteksi Fisik Bahan Nuklir)

(8) Peraturan Kepala BAPETEN Nomor NOMOR 3 TAHUN 2010 tentang Desain Sistem Penanganan dan Penyimpanan Bahan Bakar Nuklir untuk Reaktor Daya

\section{SEIFGARD}

(1) Peraturan Kepala BAPETEN Nomor 2 Tahun 2005 tentang Sistem Pertanggungjawaban Dan Pengendalian Bahan Nuklir

(2) Peraturan Kepala BAPETEN Nomor 9 Tahun 2006 tentang Pelaksanaan Protokol Tambahan Pada Sistem Pertanggungjawaban Dan Pengendalian Bahan Nuklir
(3) Peraturan Pemerintah Nomor 43 Tahun 2006 tentang Perizinan Reaktor Nuklir

(4) Undang Undang Nomor 10 Tahun 1997 tentang Ketenaganukliran

(5) Peraturan Kepala BAPETEN Nomor 9 Tahun 2008 tentang Penyusunan dan Format Deklarasi Dalam Pelaksanaan Protokol Tambahan Pada Sistem Pertanggungjawaban Dan Pengendalian Bahan Nuklir

\section{PERTANGGUNGJAWABAN KERUGIAN NUKLIR}

Peraturan Pemerintah Nomor 43 Tahun 2006 tentang Perizinan Reaktor Nuklir

(1) Undang Undang Nomor 10 Tahun 1997 tentang Ketenaganukliran

(2) Peraturan Pemerintah Nomor 46 Tahun 2009

tentang Batas Pertanggungjawaban Kerugian Nuklir

(3) Peraturan Kepala BAPETEN Nomor NOMOR 3 TAHUN 2010 tentang Desain Sistem Penanganan dan Penyimpanan Bahan Bakar Nuklir untuk Reaktor Daya 